\title{
Non-palimpsested crowded Skolithos ichnofabrics in a Carboniferous tidal rhythmite: Disentangling ecological signatures from the spatio-temporal bias of outcrop
}

\author{
HAMILTON A. AlLPORT*, NEIL S. DAVIES* (D), ANTHONY P. SHILlito†, EMILY G. \\ MITCHELL $\$$ and SEÁN T. HERRON* \\ *Department of Earth Sciences, University of Cambridge, Downing Street, Cambridge, CB2 3EQ, UK \\ (E-mail: nsd27@cam.ac.uk) \\ $\dagger$ Department of Earth Sciences, University of Oxford, South Parks Road, Oxford, OX1 3AN, UK \\ $\$$ Department of Zoology, University of Cambridge, Downing Street, Cambridge, CB2 3EJ, UK
}

Associate Editor - M. Gabriela Mángano

\begin{abstract}
A heterolithic tidalite succession yielding spring-neap bundles is newly reported from a mid-Carboniferous (Serpukhovian) section of the Alston Formation of Northumberland, England. The rhythmite records deposition over an interval that can be confidently calibrated to at least 84 lunar days, and attests to a non-negligible tidal range in parts of the Northwest European Seaway in the late Mississippian. The tidalite is notable for the presence of a striking crowded Skolithos ichnofabric on both bedding planes and in vertical section. Bedding plane expressions of the ichnofabric reveal true substrates of sand piles excavated during burrow construction, in addition to an apparently remarkable equal spacing between individual burrows that is shown to be genuine through pair correlation function analysis. These characteristics show that the burrowed horizons were registered by contemporaneous ichnocoenoses, with no palimpsesting of burrows. The irregular vertical distribution of burrow horizons, despite a near-continuous semi-diurnal record of sedimentation, is suggested to be an artefact of spatial patchiness of burrowing communities in the depositional environment; imperfectly registered in a vertical profile with high-temporal, low-spatial resolution. The succession proves that burrow palimpsesting is not an inevitable ichnological conclusion of sedimentary stasis, and attests to intermittent palaeoecological fidelity of the stratigraphic record at the small spatio-temporal scales recorded at outcrop.
\end{abstract}

Keywords Alston Formation, burrows, chronostratigraphy, Northumberland Basin, stratigraphic time, tidalite, trace fossil, true substrate.

\section{INTRODUCTION}

The diurnal or semi-diurnal tidal deformation of marine waters manifests in coastal regions as a dominant incoming flood tidal current and subordinate outgoing ebb tidal current, each punctuated by a tidal stillstand at high and low tide (e.g. De Boer et al., 1989; Dalrymple et al., 1991; Archer \& Johnson, 1997; Mazumder \& Arima,
2005; Kvale, 2012). Sedimentary signatures ascribed to these bidirectional currents and repeated fluctuations in current energy are collectively referred to as tidalites and include features such as herringbone/bipolar crossstratification, reactivation surfaces and cyclic rhythmites (e.g. Nio \& Yang, 1991; Wells et al., 2005; Davis, 2012. Tidalites that comprise flatlaminated or laterally-accreted rhythmite 
successions, consisting of heterolithic laminae of varying thickness, have special value as they can preserve continuous sedimentary records on timescales from the semi-diurnal to annual; archiving spring-neap and longer tidal cycles in addition to daily tides (e.g. Kvale, 2012) and providing insights into the long-term evolution of the Earth-Moon system (e.g. Williams, 1989; Coughenour et al., 2013). Yet, considering that these processes have been ubiquitous and continuous in coastal waters throughout Earth history, tidal rhythmites are relatively uncommon in the global sedimentary-stratigraphic record. This is because not all flood/ebb currents in nature attain (or attain sufficiently distinct) critical velocities to create heterolithic rhythmites, in addition to the propensity for rhythmic laminae to be disrupted or destroyed by other common nearshore sedimentary processes including storm/wave action and bioturbation (e.g. De Boer et al., 1989; Davis, 2012). When instances of ancient tidal rhythmites can be unequivocally identified, having escaped such reworking to become interred in the sedimentary-stratigraphic record, they have extreme value as high-resolution sedimentary chronometers that permit the recognition of signatures that can be accurately chronicled on timescales of days to months.

This study presents evidence for previously unrecognized subhorizontal-laminated heterolithic tidal rhythmites, cropping out in midCarboniferous strata of the Northumberland Basin, northern England. The rhythmites act as high-resolution records of sedimentation over a continuous interval of at least 84 days and are especially notable for the presence of crowded Skolithos ichnofabrics at several horizons, stochastically distributed throughout tidal bundles, and with no evidence for palimpsesting of burrows. The accuracy of this semi-diurnal sedimentary-stratigraphic chronometer, coupled with evidence for contemporaneous communities of burrowing organisms active during temporally constrained intervals of a few days, renders this outcrop an exceptional window onto high-frequency palaeoecological processes in the mid-Carboniferous and provides general insight into the significance of non-palimpsested ichnofabrics at outcrop.

\section{GEOLOGICAL SETTING}

The outcrop described here is found at Saltpan How (55 $\left.44^{\circ} 03.5^{\prime \prime} \mathrm{N}, 01^{\circ} 57^{\prime} 42.7^{\prime \prime} \mathrm{W}\right)$ at the north end of Cocklawburn Beach, $4 \mathrm{~km}$ southeast of Berwick-upon-Tweed, Northumberland (Fig. 1), and has only relatively recently become exposed. It occurs directly below the remains of an old cliff top road, truncated by a cliff collapse in the 1950s [dated from historic records (Carlton \& Summerling, 2017) and Ordnance Survey maps]. Extensive landslip debris from the collapse created soft earth cliffs that concealed any outcrop for decades; however, accelerated coastal erosion between 2012 and 2018 has removed this (and further bedrock), exposing the present outcrop (Fig. 1; Northumberland County Council, 2012, 2020).

The exposed cliff face comprises strata of the Mississippian-aged Alston Formation, which is the middle of three units of the midCarboniferous Yoredale Group (Fig. 1; Dean et al., 2011). All the formations of the Yoredale Group are characterized by repeating cyclothems that can comprise sandstones, shales, coals and limestones, but are differentiated by their age and an upwards-decreasing frequency of carbonates as the units become dominated by terrigenous strata (Reynolds, 1992; Frank \& Tyson, 1995; Dean et al., 2011; Booth et al., 2020). The strata were deposited within the Tweed SubBasin (Northumberland Basin), in the foreland region of the Variscan orogenic belt, at a subequatorial palaeolatitude (Leeder et al., 1989; Chadwick et al., 1995; Fraser \& Gawthorpe, 2003; Torsvik \& Cocks, 2016).

Named limestone marker horizons occur throughout the Yoredale Group, recording transgressive cyclicity on frequencies of $100 \mathrm{ka}$ or less, and governed by both glacio-eustasy and local tectonics (Tucker et al., 2009; Waters et al., 2014; Booth et al., 2020). They are biostratigraphically correlated to regional substage level throughout northern Britain, using miospore and foraminifera assemblages (Turner \& Spinner, 1992; Cózar \& Somerville, 2012, 2020, 2021; Ingrams et al., 2020). The tidalite beds described here occur above the Eelwell Limestone, which is dated to the late Brigantian regional substage ( $c$ a 329 Ma; early Serpukhovian) (Cózar \& Somerville, 2020, 2021; Ingrams et al., 2020). Although the stratigraphy immediately overlying the Eelwell Limestone is complicated and repeated by a series of minor thrust faults, the presence of the 'Acre Coal' seam at the base of the studied outcrop (Turner \& Scrutton, 1995) stratigraphically locates it to within $10 \mathrm{~m}$ above the marker limestone. 


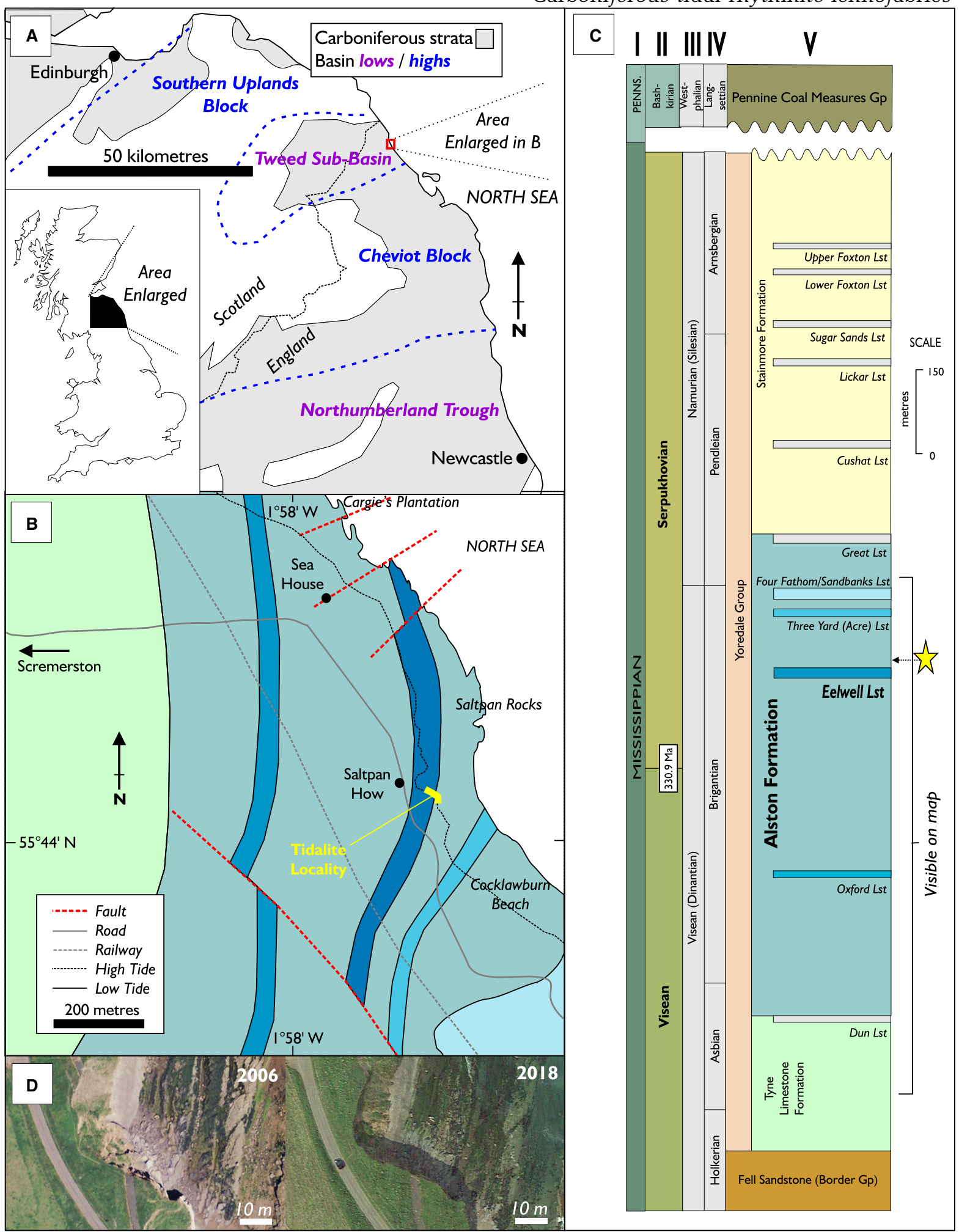

Fig. 1. Geological context of the tidalite locality. (A) Location within the Tweed Sub-Basin. (B) Geological map of the locality. (C) Stratigraphy of the Yoredale Group, colour coded to map, showing stratigraphic position of the tidalite (star) immediately above the late Brigantian Eelwell Limestone in the Alston Formation. International and regional stratigraphy after Richards (2013) and Cózar \& Somerville (2021): I - global subperiod; II - global stage; III - regional subsystem/stage; IV - regional substage; V - local lithostratigraphic units. (D) Satellite images from 2006 and 2018 showing how recent coastal retreat has exposed the tidalite outcrop, at the south end of the cliffs shown. (2006 image (c) Infoterra Limited \& Bluesky, (c) Google Earth. 2018 image (c) CNES/Airbus, () Google Earth). 


\section{SEDIMENTARY CHARACTERISTICS OF THE SALTPAN HOW OUTCROP}

\section{Description}

The studied section commences near the Acre Coal (Fig. 2), which rests on top of fine-grained sandstones with prominent stigmarian root casts. The $30 \mathrm{~cm}$ thick coal seam is succeeded by a $2.5 \mathrm{~m}$ thick heterolithic package of dark grey-coloured siltstone with 0.5 to $2.0 \mathrm{~mm}$ thick laminae and lenses of very fine-grained sandstone. In the uppermost $80 \mathrm{~cm}$ of this package, the sandstone laminae are organized into the rhythmic bundles that are the focus of this study (Fig. 3). The upper part of the package is truncated by $50 \mathrm{~cm}$ of amalgamated sandstone laminae with prominent wave ripple lamination, soft-sediment deformation, and an erosive base, which itself passes upwards into further heterolithic packages that lack regular bundles of sandstone laminae (Fig. 2).

The studied heterolithic package (Fig. 3) comprises an apparently continuous package of horizontal to sub-horizontal laminae, but close inspection reveals that it is frequently interrupted with minor disconformities that are marked by faint changes in lamina dip or shallowly erosive bounding surfaces (Fig. 3D). The subtlety of the disconformities means that they can remain cryptic at a small scale in the weathered natural outcrop, so it is problematic to confidently divide the succession into conformable packages. Yet, despite this, the uppermost $80 \mathrm{~cm}$ of the heterolithic package can clearly be seen to be organized into 2 to $5 \mathrm{~cm}$ thick bundles that typically consist of individual 0.1 to $3.0 \mathrm{~mm}$ thick sandstone and siltstone laminae, punctuated by 1 to $3 \mathrm{~cm}$ thick intervals of vertically-continuous siltstone (Figs 3 and 4).

The apparent number of sandstone laminae in each bundle is dependent on the precise vertical profile along which they are counted, because even over a lateral distance of a few millimetres some laminae can be seen to be lenticular and discontinuous, and some have shallowly erosive bases (Fig. 5). Additionally, accurate counts can occasionally be hindered by post-depositional micro-thrusts internal to the rock package (Fig. 5C).

To mitigate against both the lamina-scale and bundle-scale lateral discontinuity, counts and measurements of laminae were restricted to one ca $20 \mathrm{~cm}$ thick vertical interval of six bundles, which could confidently be traced uninterrupted along the length of the outcrop (Figs 3 and 5). Tallies of number of laminae and thickness of individual laminae were taken in 15 vertical transects of these six bundles; as five groups of three vertical counts, spaced $5 \mathrm{~cm}$ horizontally, across the $11 \mathrm{~m}$ wide outcrop. Ignoring instances where the uppermost bundle had been erosionally-truncated, these counts revealed that each bundle consists of between nine and 20 discernible sandstone laminae, with the majority consisting of 12 to 16 laminae (mean ca 14; Fig. 6A). Measurements of the thickness of individual sandstone laminae reveal that they are thickest (typically 1 to $2 \mathrm{~mm}$ ) towards the middle of each bundle, and thinner (typically $<0.5 \mathrm{~mm}$ ) towards the top and bottom of each bundle (Fig. 6B).

\section{Interpretation of tidal rhythmites}

The heterolithic bundles are interpreted as tidal rhythmites, with cyclic variations in lamina thickness and lithology recording changes in current velocity associated with lunar/solar cycles (e.g. Kvale, 2012). Ideal instances of tidal rhythmites permit the recognition of a hierarchy of semi-diurnal, diurnal, fortnightly (neapspring) and longer-recurrence tidal events, variably synchronized to the synodic (lunar; 29.52 day) or tropical (27.32 day) month (e.g. Archer et al., 1991; Kvale, 2006, 2012). Such instances can be invaluable in determining palaeotidal range, lunar retreat or regional palaeogeography, but are dissimilar from the examples described here because: (i) they are most commonly described from core rather than natural rock outcrop, meaning that laminae can be more clearly discerned within a spatiallyconfined sample; (ii) they can be far more vertically extensive, with additional value for determining longer-term events; and (iii) the best examples contain few disconformities and consist of laterally-continuous laminae.

The bundles from the Alston Formation are imperfectly registered in a naturally-weathered rock outcrop of limited spatial extent (for example, Fig. 4), where the propensity for lateral discontinuity of individual laminae and bundles is more apparent than in a core sample. Despite this, they exhibit four regular and repetitive characteristics that strongly indicate that they are deposits arising from cyclic neap-spring variability in current strength: (i) the bundle laminae are always evident as couplets of sandstone and siltstone, analogous to modern 


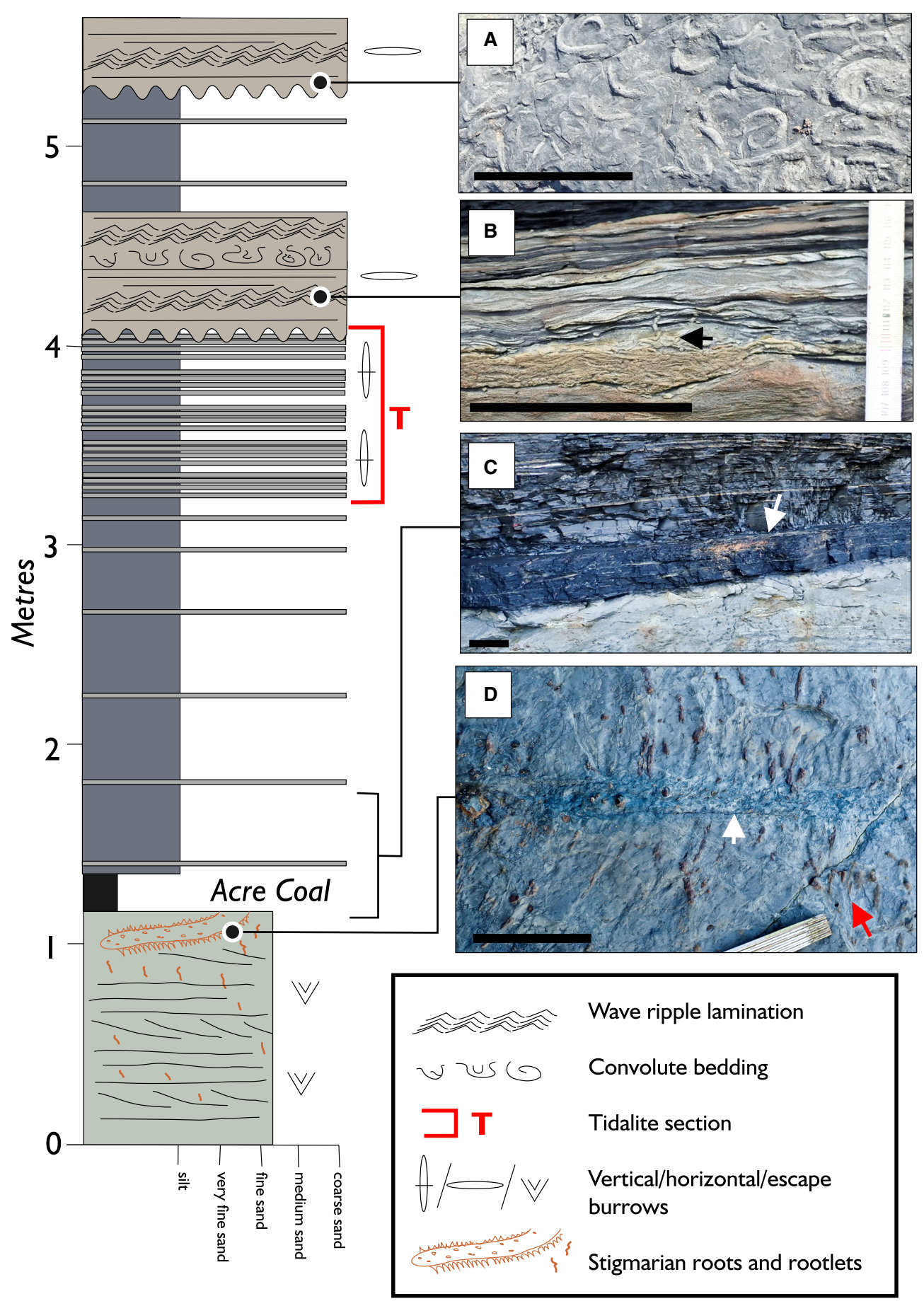

Fig. 2. Sedimentary log and photographs showing context of tidal bundles. Note that the log is simplified to show dominant grain-size as the section is heterolithic on many scales. (A) Horizontal Planolites burrows in overlying strata. (B) Wave ripple lamination and sub-horizontal Teichichnus burrows (arrowed) in overlying sandstones. (C) Acre Coal marker unit (top arrowed) below tidalite section. (D) Seat-earth at top of sandstone below the Acre Coal, exhibiting horizontal stigmarian root casts (white arrow) with root hairs preserved as ferrous iron-rich sediment (red arrows). Scale in each image is $10 \mathrm{~cm}$.

rhythmites where the flood, or flood and ebb, tidal currents are sufficient to move sand, and intervening episodes of tidal stillstand are marked by the settling of mud from suspension (e.g. Nio \& Yang, 1991); (ii) despite local variability, the bundles never contain fewer than 

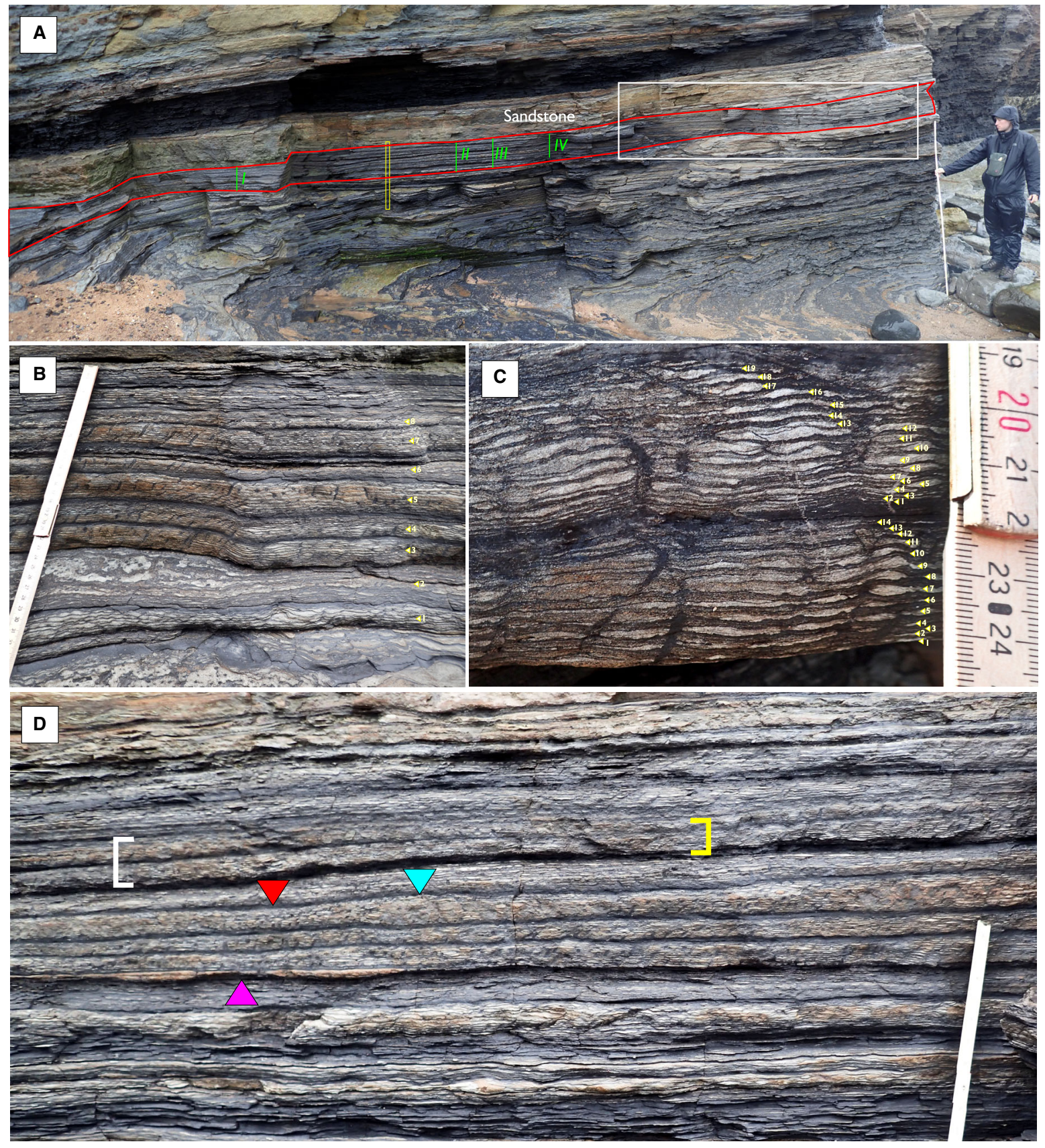

Fig. 3. Tidalite at outcrop at a variety of scales. (A) View of the tidalite-bearing outcrop. Tidal bundles occur throughout the heterolithic strata below the labelled sandstone, but subtle changes in the dip of laminae (for example, see white box) indicate that there are likely to be cryptic disconformities throughout. Package highlighted in red contains bundles that can be traced laterally across the outcrop without discontinuity. Yellow area is enlarged in Fig. 4. Green lines I to IV mark selected areas where laminae counts were undertaken. Measuring stick is $2 \mathrm{~m}$ long for scale. (B) Typical view of bundles of sandstone (interpreted as spring tide deposits) punctuated by thicker horizons of siltstone (interpreted as neap tide deposits). At least eight packages (numbered), can be recognized with confidence. Visible part of measuring stick is $32 \mathrm{~cm}$. (C) Close-up view of two individual bundles with sandstone laminae numbered. Reasons for variability in number of sandstone laminae discussed in the text. Visible part of measuring stick is $6 \mathrm{~cm}$. (D) Detail of upper part of package showing subtle irregularities within the rhythmite. Package shown at white bracket has slightly different dip to same package along strike (yellow bracket), where sandstone laminae have become amalgamated. Other sets of sandstone laminae exhibit thickness variation through pinching (red arrow) and swelling (blue arrow), and minor erosional discontinuities (purple arrow) bound the package. Visible part of ruler is $25 \mathrm{~cm}$. 
Fig. 4. Photomontage of vertical section through tidal bundles (location highlighted in Fig. 3), with graphic log showing 269 sandstone laminae in $80 \mathrm{~cm}$ of section. Note that the number of sandstone laminae was counted at a vertical line in the centre of the photograph - even within this spatial range counts of sandstone laminae can be variable (see Fig. 5). Laminae are arranged into bundles that are interpreted as deposits of spring-neap tidal cycles, with estimated duration of packages shown. Bundles B1 to B6 are traceable across the outcrop and are those used for lamina thickness counts in Fig. 6. Erosional and discordant contacts (highlighted red) of unknown duration interrupt these packages of consistent sediment accrual. Figure also shows frequency of burrow top horizons and depth of penetration of burrows.

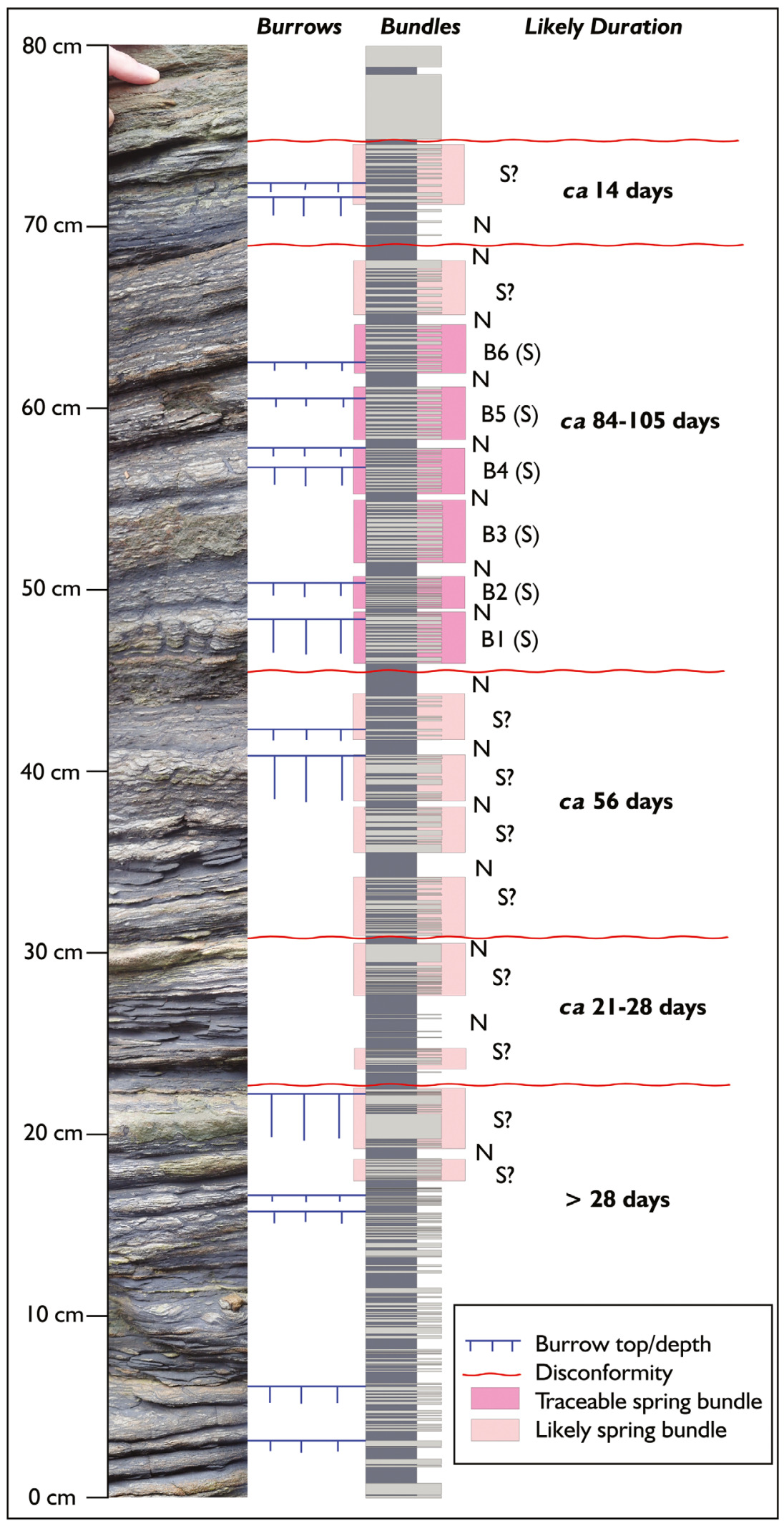



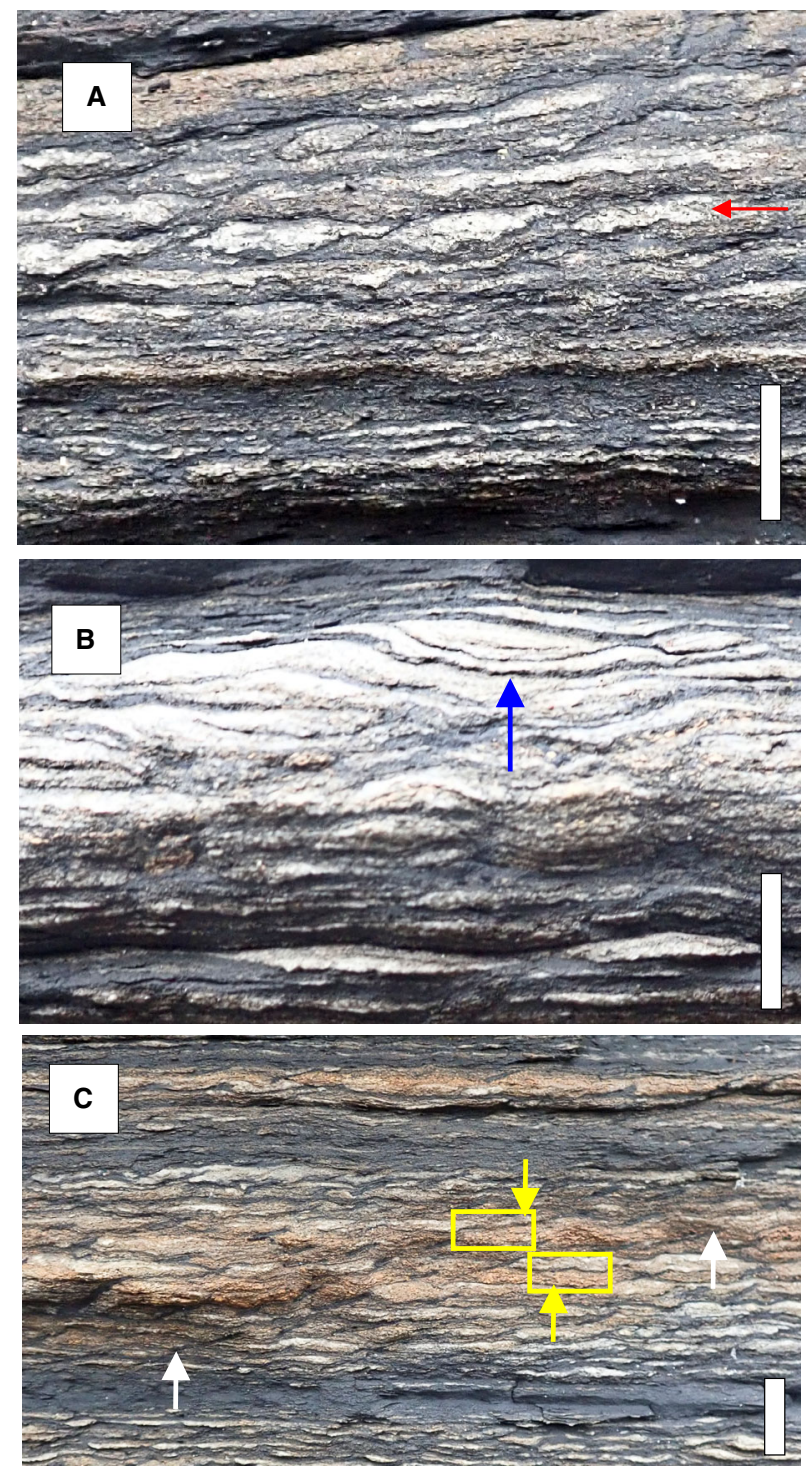

Fig. 5. Lateral discontinuity of individual sandstone laminae. (A) Discontinuity due to bundled laminae having lenticular form (arrowed), likely due to limited sand supply during deposition. (B) Discontinuity due to some sand laminae having erosive bases (arrowed). (C) Secondary discontinuity due to post-depositional compression, resulting in small thrust fractures (white arrows) that have led to stratigraphic duplication of some laminae (highlighted in yellow). Scale bar in each image is $1 \mathrm{~cm}$.

nine sandstone laminae, and never more than 20: a consistent range of sand laminae as would be expected from a semi-diurnal tidal system in which not every subordinate tidal current surpassed the critical velocity for the tractional movement of sand (e.g. Kvale, 2012). In addition, the lenticular nature of some of the sand laminae (Fig. 5A) indicates that some may be the deposits of sediment-starved ripples: thus, lamina deposition may have been less frequent than the motion of tidal currents due to limited local sediment budgets; (iii) there is consistency to the thickness of both the bundles (2 to $5 \mathrm{~cm}$ ) and the siltstone intervals ( 1 to $3 \mathrm{~cm}$ ) that separate them, attesting to a regularity in the variation of depositional energy that is attained in few non-tidal sedimentary settings. There is weak evidence that there may be a pattern of alternation between thicker and thinner bundles (for example, compare bundles 1, 3 and 5, versus bundles 2 and 4, in Fig. 4), as could be expected from the high spring tide versus the low spring tide in any one synodic or tropical month; and (iv) sandstone laminae are thicker in the middle of bundles than at the top and bottom of bundles, comparable with patterns observed in definitive tidal rhythmites, where peak lamina thickness is incrementally attained commensurate with the dominant current of the peak spring tide (e.g. Kvale, 2012).

The sedimentological context of the surrounding strata is supportive of a tidal role in deposition. The Alston Formation near Saltpan How has previously been investigated in detail from a facies model perspective by Reynolds (1992) and Booth et al. (2020), who both interpreted the presence of tidally-influenced sedimentary facies [Reynolds' (1992) Facies II tidal channel and Booth et al.'s (2020) Facies D1 interdistributary bay tidal flats]. However, neither noted the presence of rhythmite bundles, suggesting that this facies motif may be very spatially-restricted and only apparent in the most recently exposed outcrop. The positioning of the rhythmite immediately above a transgressive surface onto the Acre Coal, within a succession that locally also contains evidence for fluvio-deltaic and storminduced hummocky cross-stratification (e.g. Reynolds, 1992; Booth et al., 2020), suggests deposition within the shallow subtidal realm (Dashtgard et al., 2021). The restricted vertical and lateral extent of the rhythmite is compatible with suggestions that deposition occurred in an interdistributary bay, between some of the many localized delta lobes that typify facies models for the cyclothems of the Yoredale Group (e.g. Reynolds, 1992; Frank \& Tyson, 1995; Jones, 2007; Dean et al., 2011; Booth et al., 2020; Fielding, 2021). It appears to be a rare and fortuitously surviving record of tidal conditions within the Tweed Sub-Basin, because most such deposits that once existed were destined to 
A
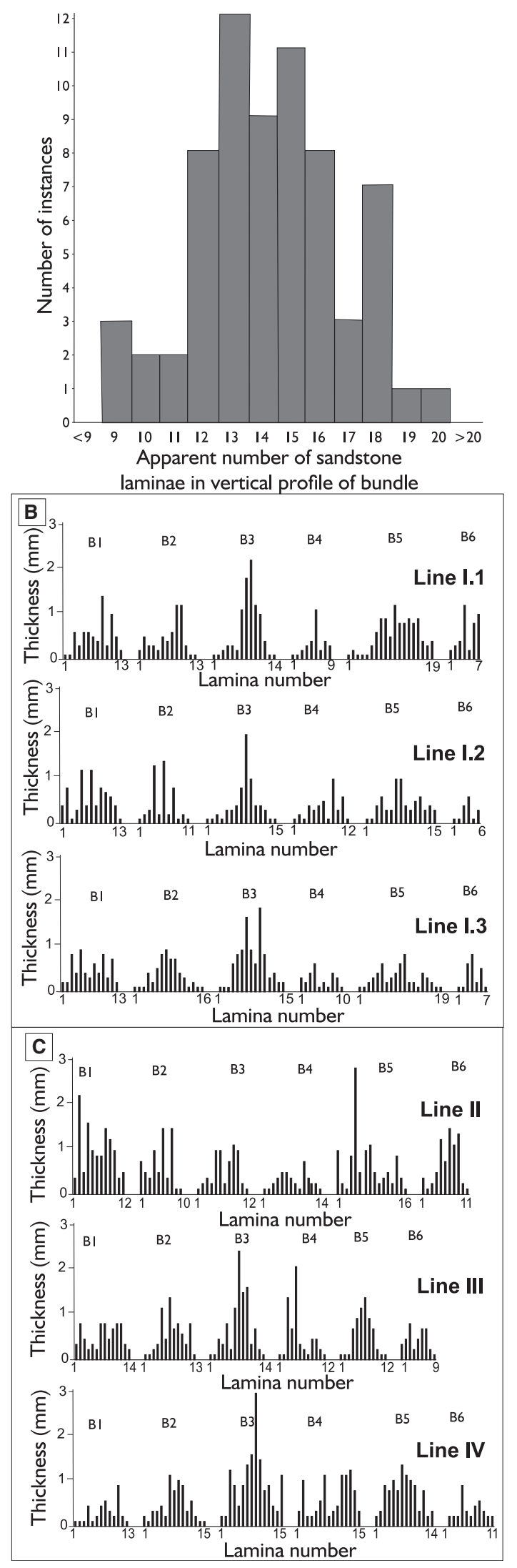

Fig. 6. Patterns of thickness variation and number of laminae in bundles. (A) Frequency of occurrence different numbers of sandstone laminae in bundles, showing a mean number of 14.1 and median of 14 . (B) and (C) Thickness of sandstone laminae in the top six bundles (B1 to B6) of the package highlighted in Fig. 3 (note that B6 can be erosionally truncated): (B) shows three vertical counts spaced $5 \mathrm{~cm}$ apart at Line I in Fig. 3; (C) shows individual examples of counts at lines II to IV in Fig. 3. Note that although individual thicknesses and number of discernible laminae are variable, there is consistency in the overall thickness of bundles and that internal laminae tend to exhibit thickest values towards the middle of each bundle.

reworking and replacement by higher energy deltaic and shallow marine facies signatures.

The limited extent and imperfect rendering of the tidal rhythmites in the Alston Formation mean that they are unsuited for detailed analysis of palaeotidal regime, and whether they were deposited on synodic or tropical rhythms (e.g. Kvale, 2006, 2012) remains uncertain. Nonetheless, several spring-neap packages can be recognized to varying degrees of certainty and estimates of sedimentation duration can be applied to individual disconformity-bounded packages of bundles (Fig. 4: where each springneap-spring-neap cycle is approximated as 28 days, between the synodic and tropical tidal rhythms). This attests to sedimentation rates of ca $15 \mathrm{~cm}$ per month, at the scale of the rhythmite package, permitting the succession to be used as an approximate chronometer for assessing the significance of ichnological signatures within it (see Ichnology of the Alston Formation Tidalites section).

The localized high sedimentation rate can be explained with reference to the hierarchy of sedimentary phenomena within deltaic environments (e.g. Bhattacharya et al., 2019, 2020; Holbrook \& Miall, 2020). Recent stratigraphic models have demonstrated how higher-order hierarchies of larger phenomena generate statistically large volumes of underfilled accommodation space between or within themselves (Ganti et al., 2020). In the case of the deltaic sedimentary setting of the Alston Formation, the generation of higher-order phenomena, such as delta lobes, would sporadically lead to localized areas of underfilled accommodation space (i.e. interdistributary bays), where archived sedimentation rates could be elevated. Most such 
accumulations would be at high risk of later reworking (for example, during reorganization of the delta), explaining the rarity of the facies signature within the Alston Formation. Yet as such facies would have been intrinsic components of the depositional environment, the random preservational sampling of a fraction, at the small scale of the described outcrop, is expected. It requires no special explanation of extraordinarily rapid sea-level change (e.g. Myrow et al., 2018) and instead is a 'frozen accident' of preservation (Miall, 2015).

\section{Context within the regional record of ancient tidalites}

Although of only limited extent, the Alston Formation rhythmites are significant for interpretations of regional palaeogeography at the time of deposition. Pre-Quaternary tidalites are rare in Britain, with only a few putative Cretaceous (Allen, 1981; Wells et al., 2010) and Carboniferous (Read, 1992; Aitkenhead \& Riley, 1996; Archer \& Kvale, 1997; O’Mara et al., 1999; Brettle et al., 2002; Wells et al., 2005) examples having been recorded previously. Of these, only a single example yields unequivocal evidence for rhythmites with tidal periodicities (Aitkenhead \& Riley, 1996; Archer \& Kvale, 1997; Brettle et al., 2002; Wells et al., 2005): a $76 \mathrm{~cm}$ thick borehole sequence of 95 heterolithic laminae from early Pennsylvanian (Kinderscoutian-Marsdenian) prodeltaic facies in the Central Pennine Basin of West Yorkshire (Aitkenhead \& Riley, 1996; Archer \& Kvale, 1997).

The paucity of tidalites in the abundant Carboniferous shallow marine sedimentary record of Britain has been ascribed to its palaeogeographic location on the Northwest European Seaway (NES) (Collinson, 1988; Wells et al., 2005). At the onset of the Carboniferous, the NES connected to the open Panthalassic Ocean both to the north of present-day Scandinavia, and to the south-west, through the Rheic Ocean between Laurussia and Gondwana (Torsvik \& Cocks, 2016). As the period progressed, the Variscan orogeny resulted in the closure of the Rheic Ocean, meaning that the NES remained open only to the far north and became increasingly epeiric in nature. This led to extremely microtidal conditions in its inner reaches (Collinson, 1988), and later Carboniferous tidal ranges for the British part of the NES have been modelled as reaching only $c a 5 \mathrm{~cm}$ in open water, and up to $1 \mathrm{~m}$ in restricted estuaries (Wells et al., 2005).
While the formation of flat-laminated heterolithic tidal rhythmites is possible under reasonably microtidal regimes (Wells et al., 2005), the example from the Alston Formation shows that the early Serpukhovian tidal range in the British part of the NES was not wholly negligible, and so may pre-date full closure of the Rheic Ocean. Further, the local basin setting and pronounced basement topography may have played a role in accentuating tidal range. At the time of deposition, the Tweed Sub-Basin was a narrow basinal low, sandwiched between the buoyant granitecored highs of the Cheviot Block to the south and Southern Uplands Block to the north (Fig. 1; Leeder et al., 1989; Chadwick et al., 1995; Fraser \& Gawthorpe, 2003). Within this basement context, it is plausible that the Tweed Sub-Basin provided the foundations for an open-mouthed embayment and would thus have experienced oceanic tides that were amplified above the regional 'norm' by resonance effects (Reynaud \& Dalrymple, 2012).

\section{ICHNOLOGY OF THE ALSTON FORMATION TIDALITES}

\section{Description}

Diverse trace fossils have previously been documented from the Alston Formation in the Northumberland Basin, including reports of Arenicolites, Beaconites, Diplocraterion, Neoione, Macaronichnus, Palaeophycus, Planolites, Skolithos, Taenidium, Teichichnus, Thalassanoides and Zoophycos (e.g. Boyd \& McIlroy, 2017, 2018; Booth et al., 2020; McLean et al., 2020). Despite this formation-level ichnodiversity, the heterolithic package described here contains only a monospecific assemblage of multiple short, mud-filled Skolithos (Fig. 7). Burrows can confidently be ascribed to Skolithos as they have a structureless infill, and lack the concentric lining of other similar vertical ichnotaxa such as Rosselia. Individual burrows are 2 to $3 \mathrm{~mm}$ in diameter and 4 to $30 \mathrm{~mm}$ in length, and are oriented vertically to sub-vertically in the strata [some particularly inclined instances may be due to tectonic shear (for example, Fig. 3B)].

The burrows penetrate through both sandstone and siltstone laminae, with no discernible lithological preference for their upper termination, but are exclusively infilled with siltstone. Vertical profile exposures of the traces exhibit no 
evidence for burrow overprinting and, where the outcrop is exposed as horizontal bedding planes, the burrows are seen to occur as spatially pervasive groupings with strikingly equant spacing between individual burrows (Fig. 7). No overlapping of burrow shafts was witnessed across 41 discrete bedding surface exposures.

A further striking feature of the burrowed horizons is that some of the visible bedding planes clearly record true substrates (i.e. preserved former water-sediment interfaces; Davies \& Shillito, 2018, 2021), because the burrow tops are seen to be rimmed by sand that was exhumed from antecedent heterolithic laminae during the registration of the burrow (Fig. 7C and D). The sand rims are demonstrably surficial features that exist only at the burrow aperture, as evidenced by a lack of deformation of adjacent sediment where burrows are seen in vertical section (i.e. attesting that these were not formed by adjustment of the burrow position in response to burial). Within the vertical $80 \mathrm{~cm}$ interval of tidal bundles, a total of 538 sandstone and siltstone laminae were counted, 15\% of which were penetrated by vertical burrows. Of the laminae, 51 were exposed as horizontal bedding planes and 15 mudstone laminae could be recognized as true substrates by virtue of the rimmed motif to the burrow tops (the remaining 36 were underdetermined due to an absence of trace fossils). The overall bioturbation index of the heterolithic package was 2 (5 to $30 \%$ bioturbation intensity), increasing to $3(30$ to $60 \%$ ) at the scale of individual burrowed laminae (Taylor \& Goldring, 1993). Counts of burrow tops in $10 \mathrm{~cm}^{2}$ quadrants on such true substrates indicate that the density of burrows was up to 14400 per $\mathrm{m}^{2}$.

The monospecific Skolithos assemblage is restricted to the tidal rhythmite facies, but there are other trace fossils in adjacent strata. In the wave ripple-laminated sandstone packages that overlie the rhythmite, examples of Planolites and Teichichnus are present (Fig. 2). In the climbing ripple-laminated sandstones below the Acre Coal, multiple escape traces can be recognized (fugichnia; Fig. 9). Escape traces are produced by an animal rapidly migrating upwards through a body of sediment that was deposited suddenly, resulting in downturned laminae, as sediment collapsed to fill the void left by the tracemaker (Ekdale et al., 1984). In this case, locally rapid sedimentation is attested to by the climbing ripple-lamination through which the escape traces penetrate.

\section{Analysis of burrow spacing}

To quantify the apparent mutual avoidance of burrow tops, spatial point process analyses (SPPA) were applied to four bedding plane exposures that each revealed at least $50 \mathrm{~cm}^{2}$ of true substrate (True Substrates 1 to 4 , hereafter T1 to T4; Fig. 8). The SPPA include a suite of different analyses to investigate the spatial distributions of points (here burrows) within a mapped area (Illian et al., 2008). They include nearest neighbour analyses which have been previously employed to investigate burrow communities (e.g. Pemberton \& Frey, 1984; Davies et al., 2009), whereby the distance from each burrow to its nearest neighbour is measured and plotted on a cumulative frequency curve. However, nearest neighbour analyses only capture local patterns because they are limited by the maximum distance between two burrows: if all specimens occur within $10 \mathrm{~mm}$ of one another, for example, then the analyses will not include any patterns greater than $10 \mathrm{~mm}$. This spatial limitation means that large-scale spatial patterns, as well as more complex patterns can be overlooked (Mitchell \& Butterfield, 2018). To capture more complex patterns over larger spatial scales, pair correlation functions (PCFs) were used, which measure how the density of points (here burrows) changes as distance increases. Where PCF $=1$, the pattern is completely spatially random (CSR), and so no underlying processes can be resolved from the observed pattern. If PCF $>1$ then the points (burrows) are aggregated or clustered together and if PCF $<1$ then the points (burrows) are spaced out or segregated (Illian et al., 2008). To test whether the observed patterns are significantly different from CSR, the observed data was compared to a homogeneous Poisson model (which models CSR) using 999 Monte Carlo simulations of CSR with the simulation envelopes defined as the highest and lowest $5 \%$ of generated data (Wiegand \& Moloney, 2013). To further aid comparisons with model fitting, the goodness-of-fit test 'pd' was calculated, where $\mathrm{pd}=0$ corresponded to no model fit to the data, and $\mathrm{pd}=1$ corresponded to a perfect model fit. If there were significant excursions outside the stimulation envelope and the homogenous Poisson model was not a good fit for the data ( $\mathrm{pd}>>$ 0.1 ), the observed pattern was described as nonrandom (Diggle, 2013).

Where small spatial-scale segregation (spacing out) of points (burrows) was observed, 

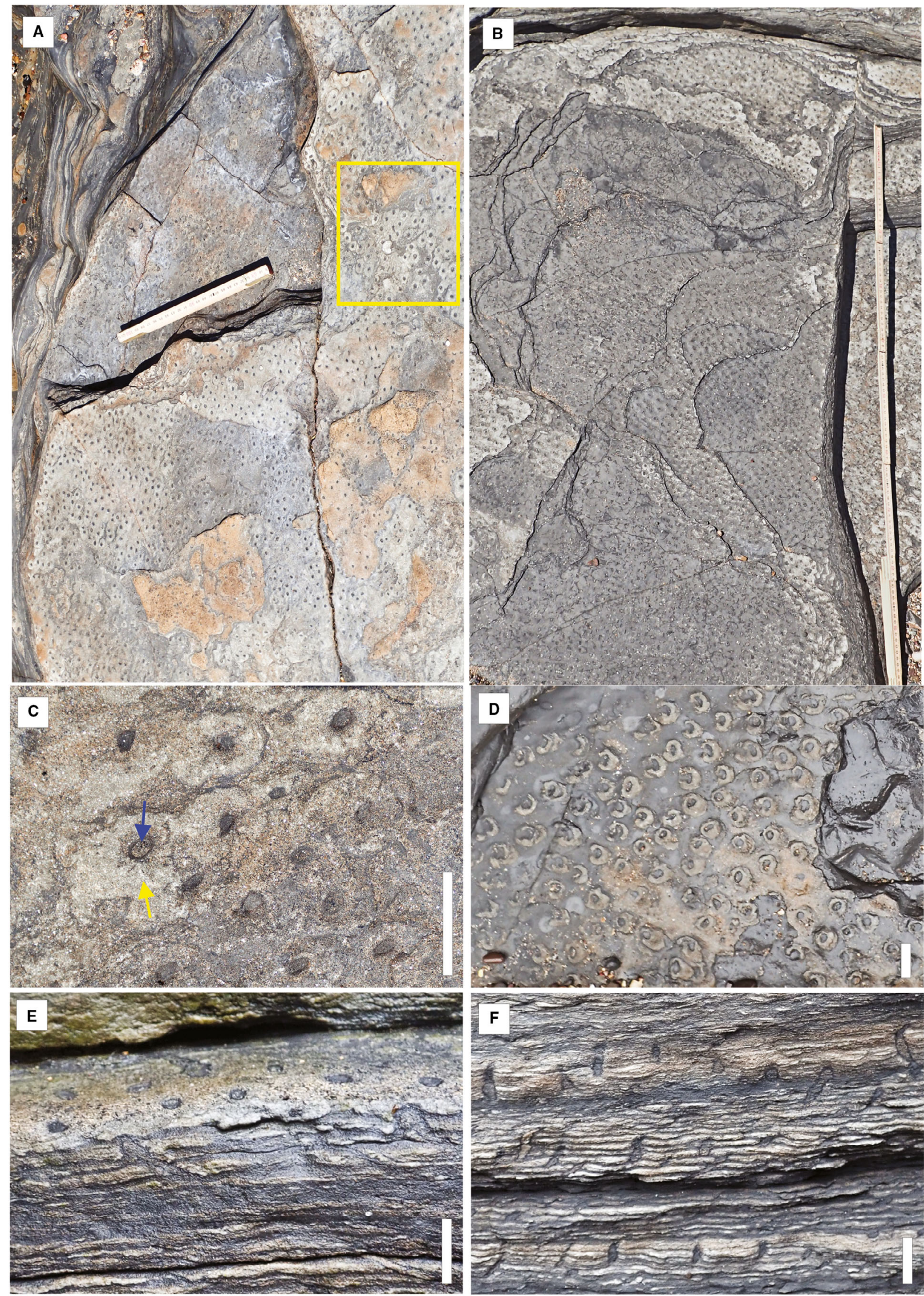

(C) 2021 The Authors. Sedimentology published by John Wiley \& Sons Ltd on behalf of International Association of Sedimentologists, Sedimentology 
Fig. 7. Ichnological characteristics of the tidal bundles. (A) True substrate bedding plane exposure showing mutual avoidance of burrows with sand rims (yellow box). Ruler is $20 \mathrm{~cm}$. (B) Eroded surface cutting through layers and showing pervasive nature of equally spaced burrows through multiple laminae. Ruler is $1 \mathrm{~m}$. (C) Close-up of burrow aperture on true substrate showing siltstone-filled inner burrow, lined with dark clay (blue arrow) and surrounded by a raised sand rim on bedding surface (yellow arrow). Scale bar is $1 \mathrm{~cm}$. (D) Multiple burrows on mud substrate with sand rims. Scale bar is $1 \mathrm{~cm}$. (E) Vertical profile immediately below true substrate showing inclined mud-lined burrows extending down through multiple laminae. Scale bar is $1 \mathrm{~cm}$. (F) Vertical expression of inclined burrows, oblique to cut of outcrop, showing mud-lined burrows at multiple horizons without overprinting (Note that while some of these burrows appear to potentially contain a meniscate infill, this is an illusion in some examples where the soft infill of the burrow has been eroded away, and the apparent lamination is the bedding behind the burrow. None of the burrows have a meniscate infill.) Scale bar is $1 \mathrm{~cm}$.

segregation models were fitted to the data (cf. Mitchell \& Harris, 2020), so that the spatial scale of avoidance could be quantified, along with the strength of such avoidance. Where points have circles of avoidance which totally exclude other points, this is known as a hardcore model, and where the density of points within this circle is reduced and does not totally exclude other points this is known as a soft-core model (Wiegand \& Moloney, 2013). For a hard-core model (total avoidance), the model parameter $p=0$, and for a soft core model with a linear relationship between the circle centre and edge $p=1$. These model-fitting analyses were performed in Programita (Wiegand \& Moloney, 2013).
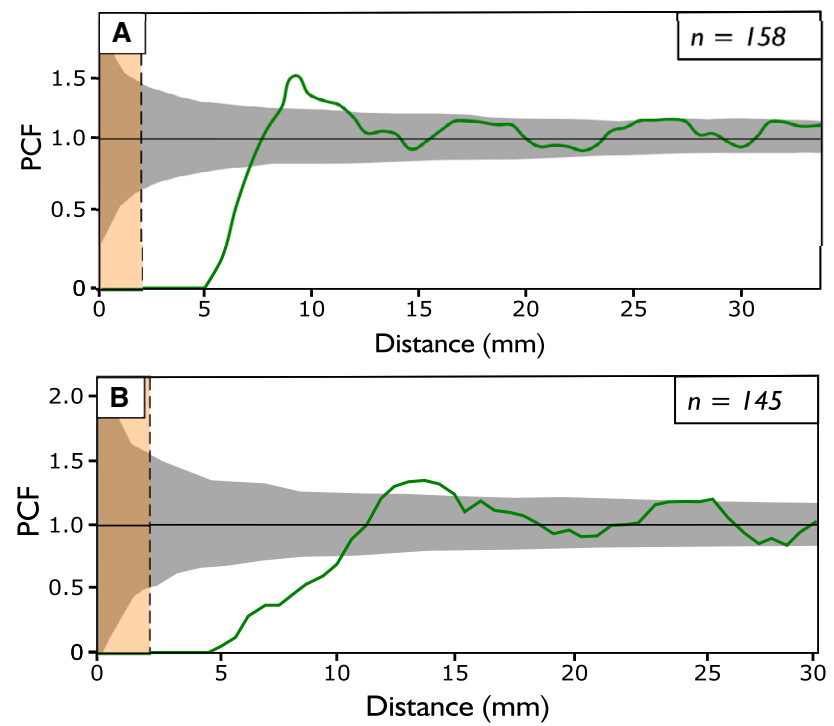

The PCF analyses found that burrow tops on all four true substrates were not-randomly distributed (all pd $<<0.001$ ) and exhibited significant segregation (avoidance) at small spatial scales $(r<10 \mathrm{~mm})$ (Fig. 8). T1, T2 and T3 exhibited significant aggregation between $10 \mathrm{~mm}$ and $15 \mathrm{~mm}$ and T4 between $8 \mathrm{~mm}$ and $12 \mathrm{~mm}$. The best-fit segregation model for $\mathrm{T} 1$ had an avoidance radius of $5 \mathrm{~mm}$, with a parameter of 0.5 ( $\mathrm{pd}=0.446), \mathrm{T} 2 \mathrm{had}$ an avoidance radius of $13 \mathrm{~mm}$, with a parameter of $0.3(\mathrm{pd}=0.645)$, T3 had an avoidance radius of $6 \mathrm{~mm}$, with a parameter of 0.05 ( $\mathrm{pd}=0.814$ ) and $\mathrm{T} 4$ had an avoidance radius of $4 \mathrm{~mm}$, with a parameter of 0.05 (pd $=0.290)$. These analyses show that T1, T3 and T4 all exhibited strong avoidance behaviour
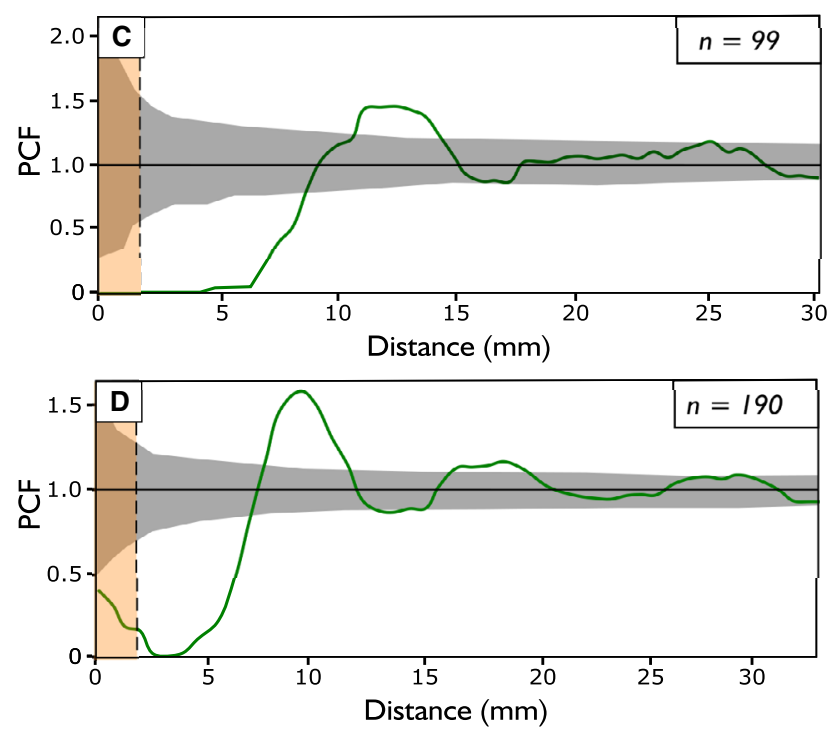

Fig. 8. Pair correlation functions (PCFs) for samples T1 to T4. The $\mathrm{x}$-axis is the distance between burrows in millimetres. The y-axis is the PCF value, whereby PCF $=1$ indicated complete spatial randomness (black line on plots), PCF $<1$ indicates segregation/spacing out of burrows and PCF $>1$ indicates aggregation of burrows. The grey area is the Monte Carlo simulation envelope (999 simulations with $5 \%$ minimum and maximum values taken as the envelope). The green lines are the observed data for; (A) T1, (B) T2, (C) T3 and (D) T4. Note that for T2 the observed slope of segregation is shallower than for T1, T3 and T4, indicating weaker avoidance behaviour. 
(demonstrated by the parameter 0) around the burrows, with varying degrees of distance from the burrows (4 to $6 \mathrm{~mm}$ ). This behaviour is consistent with strong restrictions for the burrowmakers on proximity to each other. T2 exhibited a weaker segregation behaviour (parameter $=0.3$ ) over a larger spatial scale of 13 cells, which could suggest that the constraints on proximity/ avoidance for the T2 community were more diffuse, but may more likely be an artefact of imperfect recent erosion and exposure, with some burrow tops being masked by remnants of overlying laminae.

\section{Interpretation}

\section{Tracemakers}

Skolithos is a facies-crossing trace fossil with a Phanerozoic range, and the ichnogenus most likely exemplifies behavioural convergence amongst a wide range of invertebrate tracemakers (Curran \& Frey, 1977; Knaust, 2017; Knaust et al., 2018). However, some dense, monospecific assemblages of Skolithos have previously been ascribed to the activity of communities of phoronids ('horseshoe worms') (Sundberg, 1983; Emig, 2010; Knaust et al., 2018). Phoronids are one of the smallest phyla of invertebrates, closely related to brachiopods, and have an evolutionary history extending back from the present until at least the Devonian (Emig, 1982; Santagata, 2015). In the case of the Alston Formation burrows, modern analogue is strongly supportive of tracemaker organisms that behaved similarly to phoronids. Recent examples of the phylum construct mud-lined burrow tubes in soft-sediment, which have equivalent dimensions ( 1 to $3 \mathrm{~mm}$ diameter, $<15 \mathrm{~cm}$ length: Larson \& Stachowicz, 2009) and densities (for example, the modern species Phoronis psammophila are seen up to 15 to 18000 per $\mathrm{m}^{2}$ : Emig, 1982) to the ichnofossils. Phoronids also have a strong environmental preference for intertidal to shallow subtidal habitats, and are mostly found at 0 to $70 \mathrm{~m}$ water depth (Ronan, 1978; Emig, 1982; Larson \& Stachowicz, 2009). Additionally, as recent phoronids filter-feed from burrow apertures with lophophore nets, they exhibit mutual avoidance to deter overlying of lophophores, thus encouraging equant burrow spacing (Ronan, 1978; Emig, 1982; Pemberton \& Frey, 1984). Finally, recent phoronids can retreat into their tubes during intervals when sediment is actively being deposited on their colonized substrate, and their re-emergence after sedimentation events is known to produce rims of sediment around their burrow apertures (Sundberg, 1983), with a strong similarity to the aperture rims seen in the Alston Formation.

Tracemakers similar to other known vermiform taxa appear less likely candidates. Nemerteans are known to produce simple vertical burrows with a passive fill, amongst a range of other, more complex burrow morphologies (Knaust, 2010). However, as nemerteans are largely predatory and have burrows that typically occur in low densities (Thiel \& Kruse, 2001), there is little analogy with the dense associations of non-randomly spaced burrows, which are most easily explained through mutual avoidance of filter feeding organisms. Terebellid polychaetes typically produce burrows with walls consisting of concentric muddy laminae (such as in Rosselia) in which brick-like parcels of sediment can sometimes be observed (Schäfer, 1972; Aller \& Yingst, 1978; Nara, 1995). Such features are not present in the Alston Formation Skolithos, suggesting that tracemakers similar to terebellid polychaetes were unlikely.

The tracemakers of the ichnofossils from adjacent strata were likely different organisms due to the different dimensions and morphologies of the burrows. Planolites and Teichichnus have each been ascribed to a cosmopolitan range of marine invertebrate tracemakers (Keighley \& Pickerill, 1995; Knaust, 2018), although the large dimensions of the former (Fig. 2) suggest that molluscs (bivalves) were most likely the tracemakers (Keighley \& Pickerill, 1995). Escape traces similar to those seen in Fig. 9 are known to be created by semi-sessile bivalves or vermiform organisms (Ekdale et al., 1984).

\section{Ichnocoenoses}

The term 'ichnocoenosis' has been variably applied in trace fossil studies (see Keighley \& Pickerill, 2003; McIlroy, 2004) and taken to mean either an approximation of a single community of traces that co-existed (e.g. Bromley \& Asgaard, 1991), or a simultaneous community of traces that co-existed on the same substrate (Ekdale et al., 1984; Ekdale, 1985). Pickerill (1992), Keighley \& Pickerill (2003) and Mcllroy (2004) objected to the latter usage on the basis that it can be impossible to determine burrow synchronicity. However, in the case of the Alston Formation traces, the recognition that burrows have upper terminations on preserved true substrates (Davies \& Shillito, 2018, 2021), the lack of overprinting of burrows, and the 

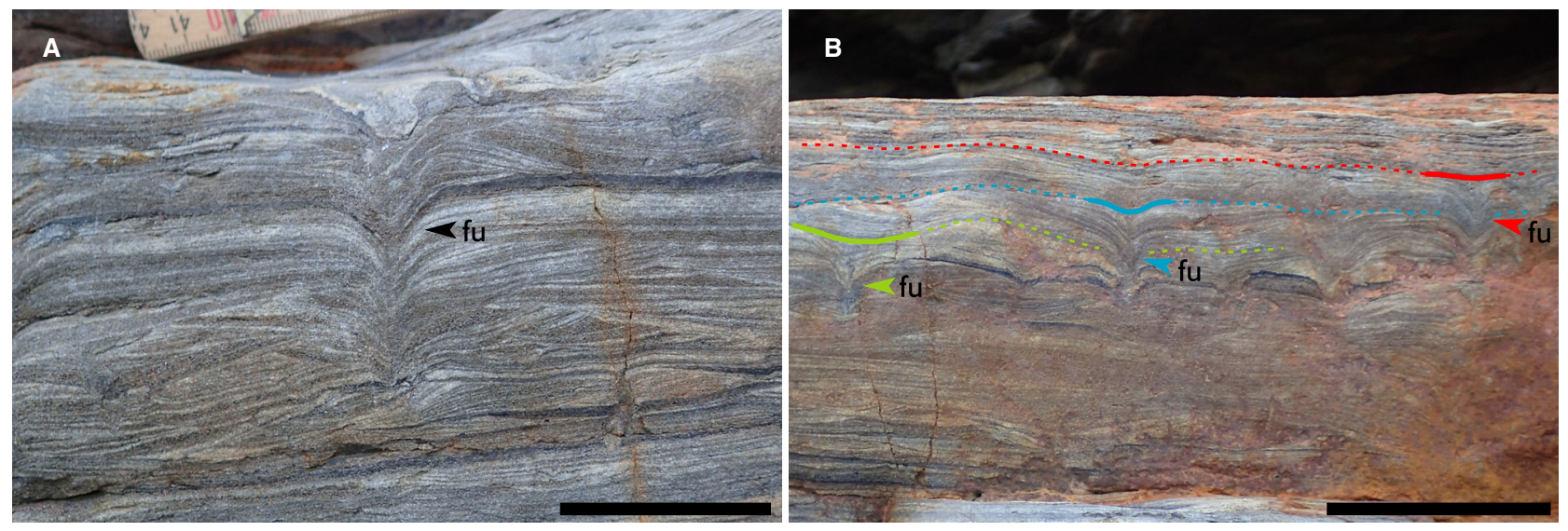

Fig. 9. Escape traces (fugichnia) attesting to locally rapid deposition, from the sandstone underlying the Acre Coal. (A) Downturning of laminae around fugichnia (fu) within climbing wave-ripple laminated sandstone. (B) Fugichnia at different iterations of the lithic surface (highlighted), suggesting pulsed rapid input of sediment. Scale bar in both images is $5 \mathrm{~cm}$.

evidence for continuous daily sedimentation, implies that burrows which occur on the same bedding surfaces were produced during the same short colonization windows, forming discrete contemporaneous ichnocoenoses in the sense of Ekdale et al. (1984) and Ekdale, (1985). This means that each individual burrowed horizon was formed by a simultaneous community of tracemakers living on the same substrate, rather than being formed through repeated and palimpsested burrow activity throughout an extended colonization window. The dominant characteristic of the Alston Formation tidalite ichnoceonoses is that they are monospecific, recording communities solely consisting of the Skolithos tracemaker, to the exclusion of other benthic fauna.

This ichnological signature contrasts with that seen in other tidalites of similar age, such as the Tonganoxie Sandstone of Kansas, USA. There, vertical burrows are rare within the tidalite facies and the associations are dominated by surficial trackways and trails (Buatois et al., 1998). This difference is explained as in the Tonganoxie tracemakers arrived from neighbouring environments during colonization windows (Buatois et al., 1997), whereas the Alston tracemakers may have settled directly from the water column, and hence were able to exploit the full colonization window.

\section{Ichnofabric and bioturbation index}

Although the burrowed horizons exhibit a crowded Skolithos ichnofabric, the bioturbation index of the horizons is relatively low (BI 2 to 3;
Taylor \& Goldring, 1993). In part this is an artefact of the equant burrow spacing, which may have had a minimum separation distance. It is also a result of the fact that no convincing overprinting can be observed in the section: wherever vertical burrows are seen, they share a common upper termination layer. Additionally, the irregular vertical distribution of burrowed laminae, separated by non-burrowed stratigraphic intervals, means that no instances of palimpsesting into antecedent burrowed layers were witnessed. These traits imply that, while the sedimentary environment in which the tidalite was deposited was clearly amenable to the tracemakers, burrowing was never pervasive everywhere. The vertical expression of intermittent burrowed laminae, colonized to their maximum possible extent, but separated by laminae that lack burrows, is explainable as a stratigraphic translation of an uneven spatial distribution of burrowed patches within the depositional environment (Miller \& Smail, 1997; Dashtgard, 2011; Marenco \& Hagadorn, 2019; Davies \& Shillito, 2021). Supporting analogue comes from comparison with modern substrates dominantly colonized by vertically burrowing filter feeding organisms. Modern phoronid burrows are known to occur in dense patches, spatially segregated by uncolonized regions of substrate (Ronan, 1978). More generally, Dashtgard (2011) analysed the substrates of Boundary Bay, Canada, and observed that there the total area occupied by organisms rarely exceeded $3 \%$, which would correspond to a bioturbation index of only 1 if translated to the rock record. 
Attaining greater bioturbation intensities requires an extended colonization window, which would not have been afforded by the semi-diurnal sediment accrual of the Alston Formation tidalite.

\section{Ichnofacies}

The overall trace fossil assemblage of the Alston Formation (Boyd \& McIlroy, 2017, 2018; Booth et al., 2020; McLean et al., 2020) is comparable to the recently described Phycosiphon and Rosselia ichnofacies (MacEachern \& Bann, 2020). These ichnofacies have been defined to describe prodelta and delta front trace fossil assemblages and may be especially useful in subdividing Carboniferous cyclothem successions (Fielding, 2021). However, while the ichnofauna of the Alston Formation as a whole is reasonably diverse, and dominated by abundant deposit feeding traces (for example, Teichichnus, Zoophycos), these traces typically occur in low diversity or monospecific trace fossil associations (Booth et al., 2020), similar to the Skolithos assemblage discussed here. As such it is likely that different parts of the Alston Formation cover the full range of deltaic subenvironments typified by the Phycosiphon and Rosselia ichnofacies (MacEachern \& Bann, 2020). The monospecific segregation of ichnogenera suggests that the broader depositional setting was partitioned ecologically (Shillito \& Davies, 2020), with filter-feeding organisms preferentially inhabiting sheltered areas (for example, as recorded by the tidalite), and deposit feeding organisms occupying wave-dominated regions and offshore carbonates, where interstitial food sources were plentiful.

\section{INTEGRATING TEMPOS OF SEDIMENTATION AND ECOLOGY}

Trace fossils can be used to add definition to our understanding of sedimentation rates at outcrop, both in terms of an understanding of the time taken for burrows to be excavated (Gingras et al., 2008) and a recognition that burrows are commonly registered during intervals of sedimentary stasis (Tipper, 2015), when the temporary cessation of local sediment accrual opens a colonization window for infaunal organisms (Pollard et al., 1993). These attributes can reliably be combined to estimate a minimum time duration of burrowed true substrates, prior to their burial (Davies et al., 2019; Davies \&
Shillito, 2021). However, estimates are commonly underdetermined by an absence of evidence for the maximum duration of time over which the burrowed substrate could have persisted as the lithic surface. The Alston Formation example of synchronous ichnocoenoses and true substrates within a tidalite circumvents such limitations because they enable the comparison of timescales of burrowing activity against the tidal sedimentation rhythms recorded by the host strata. In this way, they provide an example of how the tempos recorded by sedimentary strata, extensive to the burrows that they host, can inform on the duration of burrow occupation. This scenario provides a subtle counterpart to more commonly reported tidal ichnological signatures where intensive rhythmites are preserved within traces and provide evidence for the duration of infilling of open burrow systems (Rodríguez-Tovar et al., 2019).

In the tidalite, the shortest (4 mm) burrows penetrate four or five heterolithic laminae, while the longest $(30 \mathrm{~mm})$ burrows penetrate up to 25 heterolithic laminae. On a semidiurnal rhythm, the former would be equivalent to approximately one day of accrued sediment, and the latter to five days. These values provide inflated estimates for the maximum 'lifespan' of the active burrows because at least some of the laminae that they penetrate must already have been in place prior to the initial burrow registration. On the other hand, evidence suggests that some of the burrows could remain active over more than one tidal cycle because the sediment rims to the burrow tops (Fig. 7) can be interpreted as signatures of aperture reactivation following blanketing by new sediment (e.g. Sundberg, 1983). If the shortest burrows are estimated to reflect the minimum penetrative depth at the instant of burrow initiation, then the longest examples would record burrows that remained active during the iterative accrual of 20 successive laminae (four days).

The tidal rhythmites are robust empirical evidence for short duration sedimentary timescales which prove that the colonization and occupation of the substrates by the Skolithos tracemakers was rapid and transient. Irrespective of the actual tracemaker, phoronids offer an analogy for the type of viable ontogenies that would have emerged amongst a multitude of unknown (and unknowable) tracemakers in geological history and demonstrate that unexpectedly 
expeditious registration of ichnological signatures can happen. Planktonic phoronid larvae swim in open seawater for approximately seven days, before sinking to the seabed and then undergoing a catastrophic 15 to $30 \mathrm{~min}$ metamorphosis in which they transform into juveniles with an elongate vermiform trunk (Emig, 2010; Santagata, 2015). Once a phoronid has developed this form, it can burrow downwards into soft-sediment from its posterior by utilizing hydrostatic pressure changes to coelomic fluid and metasomal muscle contractions, achieving full burial (apart from the lophophore) in as little as eight hours (Emig, 1982). The transition from a planktonic larva to an organism with a fully developed burrow can thus be achieved in less than nine hours.

From this perspective, the fact that the burrows share common horizons within a continuously deposited succession is unsurprising because the colonization of the substrate could be instantaneously instigated relative to the timeframe of the deposition of a tidal laminae couplet. However, the persistence of the active burrows for less than a week after initial registration appears unusually short, particularly as, once buried, modern phoronids are thought to have a lifespan of approximately one year (Emig \& Mittelwihr, 1999).

The lithology of the burrow infills can be used to explain this disconnect between known sedimentary and ecological timescales. The burrow infills invariably comprise siltstone, indicating that it is unlikely they were filled in during any iteration of the dominant tidal current, when a sand infill would be expected. Likewise, none of the burrows exhibit signatures of heterolithic 'tubular tidalites' (e.g. Gingras \& Zonneveld, 2015; Rodríguez-Tovar et al., 2019), that record rhythmic infill of burrows that remained open over multiple tidal cycles after abandonment. Instead, burrow abandonment appears to have unilaterally occurred during slackwater or neap tide sedimentation episodes. This suggests that these intervals were more likely to be terminal for the burrow occupants and that they may have been associated with hostile conditions for the tracemakers (for example, insufficient water depth).

The apparently short lifespan of the burrow tracemakers may also be reflective of the locally high rates of sedimentation (see section Interpretation of tidal rhythmites), if they were able to withstand, and re-adjust after, only a finite number of episodes of sediment blanketing. If substrate colonization is rapid then ambient ecological conditions such as salinity, oxygen levels, or water temperature may appear favourable to waterborne larvae, even when longerterm sedimentation rates may be inimical. If the waters of the Alston Formation depositional environment were replete with larvae of phoronid-like organisms, opportunistic substrate colonization should be expected to have occurred throughout shallow waters, irrespective of whether local accommodation space was underfilled. In this scenario we should expect a preservational bias towards ichnological signatures of relatively juvenile 'doomed pioneers', within the tidal rhythmite facies. Elsewhere in the depositional environment, where local sedimentation rates were lower, tracemakers could achieve their full one year lifespans, but this scenario would rarely (or cryptically) be archived in the rock record due to the necessarily limited sediment accrual.

\section{DISCUSSION: ICHNOFABRICS AND THE SPATIO-TEMPORAL SCALE OF OUTCROP}

Key to understanding the significance and preservation of the Alston Formation ichnofabrics is a recognition of the spatio-temporal scale of their archive at outcrop. The tidal rhythmites provide a highly resolved temporal record of a few weeks, but only at a scale of less than two vertical metres, along a generally twodimensional $11 \mathrm{~m}$ horizontal transect (Fig. 3). In modern ecological or neoichnological studies, the monitoring of such a diminutive field of view for several weeks is uncommon, and there is limited modern analogue for how signals are registered at this unorthodox spatio-temporal scale (counterintuitively short in timescale, compared to the longevity of the host strata, and limited in spatial extent, compared to surveys of modern analogues). Figure 4 shows $80 \mathrm{~cm}$ of rhythmite consisting of 289 sandstone and siltstone laminae, where only 15 of these laminae have been colonized by burrowers, at the scale of field of view, and none are overprinted. Because the substrates recorded in the tidal rhythmites were clearly amenable for colonization, the most viable explanation for this stochastic vertical distribution of burrowed surfaces is that burrows were concentrated in patches, with a random horizontal distribution within the wider depositional environment (Ronan, 1978; Dashtgard, 
2011). Such patches were only captured for present-day observation when they overlapped with the diminutive spatial fragment of the wider environment that was destined to be archived and exposed at outcrop (cf. Marenco \& Hagadorn, 2019).

The recognition that present day outcrop has only sampled a fraction of the wider environment also provides an explanation for the nonpalimpsested nature of the crowded ichnofabrics. Whether or not ichnofabrics are nonpalimpsested, time-averaged or overprinted is dependent on a combination of variables of sedimentation rate, burrow penetration depth, patch recurrence and sedimentary stasis duration (Fig. 10). In the case of the Alston Formation: (i) the aggradation of the lithic surface was so rapid that iterative substrates persisted in sedimentary stasis only long enough for one generation of burrowers to colonize them (avoiding timeaveraging); and (ii) during the time it took for a new burrow patch to recur in the same (future outcrop) location as an antecedent patch, the thickness of sediment accrued was more than the vertical penetration of burrows (avoiding overprinting).

The controlling factors illustrated in Fig. 10 are primarily governed by local sedimentological and ecological heterogeneities that are not necessarily dependent on higher order controls, but which can be influential on the character of ichnological archives at small spatio-temporal scales. Archives with a tightly focussed temporal (high sedimentation rate) and spatial (limited outcrop extent) scale are informative on ecological heterogeneity in the depositional environment (Dashtgard, 2011), but interrogation of phenomena on a larger spatio-temporal scale (regional environment, macroevolutionary trends) requires equivalently scaled archives. Delineating the spatio-temporal context of outcrop samples should thus be a primary concern in ichnofabric analyses. The significance of the Alston Formation ichnofabrics is apparent because they are fortuitously preserved within a sedimentary chronometer, but recent advances in our understanding of stratigraphic time at outcrop suggest that similar-duration packages (potentially lacking chronostratigraphic indicators) can be expected to be encountered often. The hierarchical assembly of the sedimentary stratigraphic record means that pockets of underfilled accommodation space are frequently generated, inevitably archiving some packages of sediment that were deposited on counterintuitively 'human' timescales (Miall, 2015; Paola et al., 2018; Ganti et al., 2020; Holbrook \& Miall, 2020), at spatial scales that are captured within natural rock outcrops (Davies et al., 2019; Davies \& Shillito, 2021). The possibility that these may have been under-recognized in the past has implications for future ichnofabric studies because: (i) equifinal ichnofabric signatures can be generated through several mechanisms (Fig. 10) that may be impossible to differentiate without understanding the spatio-temporal scale of the studied package; (ii) non-palimpsested ichnofabrics (and true substrates of burrow tops) have preservation potential within underfilled

Fig. 10. Conceptual model showing how different combinations of sedimentation rate, patch recurrence, sedimentary stasis duration and burrow depth can impart variable ichnofabric motifs at outcrop. (A) Burrowed horizons may be non-palimpsested [single generation of burrowers (red)], time-averaged [multiple generations of burrows (red and blue) re-using the same substrate], or overprinted [second generation of burrows (blue) extends down into an antecedent burrowed surface (red) from overlying sediment package]. (B) Variables across a wider area (shown by multiple horizontal squares), in which sediment is accruing over time from interval t1 to tn, punctuated by intervals of sedimentary stasis (even t-numbers). Sedimentation rate refers to the rate at which individual laminae/beds accrue during a state of deposition. Patch recurrence refers to the time taken for a patch to revisit the same spatial location. Stasis duration refers to the length of time the system is not in a state of deposition (or erosion) between the deposition of successive laminae/beds. Burrow depth refers to the maximum downward penetration of burrows within an ichnocoenosis. (C) Sixteen alternative combinations of the variables in (B), and the resultant ichnological signatures that are archived in the accrued sediment (combinations of non-palimpsested, time-averaged and overprinted are shown as likely end results in real world examples, where different signatures would occur on different parts of the same surface due to local heterogeneities). Red rectangle marks a potential random sampling of the wider area at outcrop. Alston Formation rhythmites fall under scenario $I$, as low burrow depth and high sedimentation rate can be directly ascertained. Lack of regularity to burrow horizons (for example, scenario II) attests to patchiness of burrows in depositional environment. 


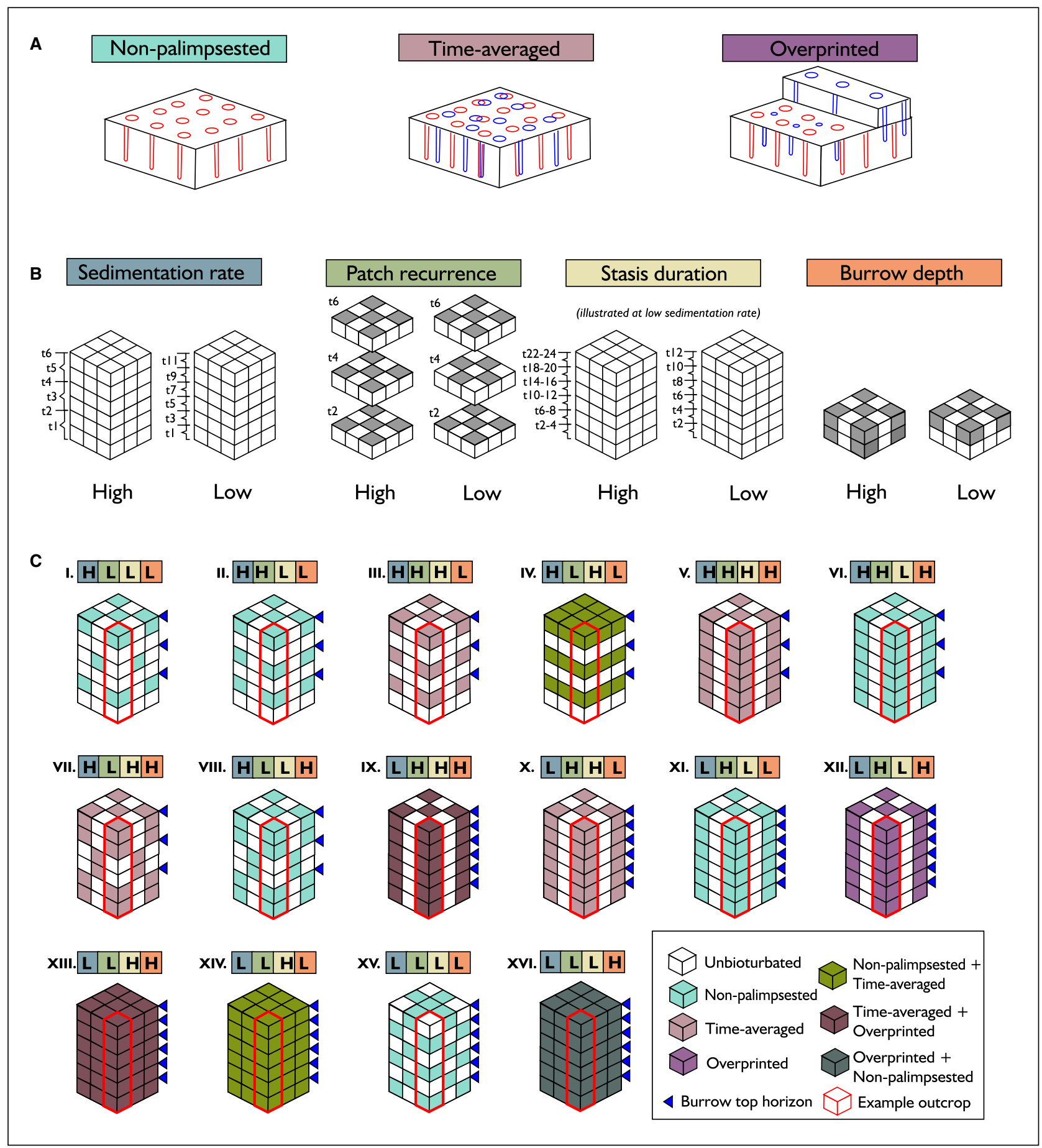

accommodation space, so prima facie assumption of time-averaging or overprinting should be avoided without direct evidence (e.g. McIlroy \& Garton, 2010); and (iii) as individual outcrops may sample only very small spatiotemporal scales, extreme caution should be exercised when interpreting their ichnofabrics in a macroevolutionary context (e.g. Tarhan et al., 2015). In compensation of these limitations, small spatio-temporal scale samples instead provide high-fidelity windows into ancient environments, where observations such as population density, recurrence frequency at site and burrow morphology (and thus, interpreted tracemakers) can be trusted as faithful palaeoecological archives. 


\section{CONCLUSIONS}

Heterolithic tidal rhythmite facies are newly reported from the Brigantian Alston Formation of the Northumberland Basin. This rare example of a British Carboniferous tidalite suggests that the Serpukhovian tidal range on the Northwest European Seaway was not wholly negligible, and that deposition may pre-date the closure of the Rheic Ocean. The rhythmite is additionally remarkable for hosting discrete crowded Skolithos ichnofabrics, which can be interpreted as faithful records of opportunistic colonization by patchy communities of shortlived vermiform tracemakers in a deltaic setting. The fact that the ichnofabrics are not palimpsested can be explained with reference to the short timescale (high sedimentation rate) and limited spatial scale of the outcrop. Extrapolating from the ichnological signatures of the tidalite, this study emphasizes that the spatio-temporal scale of trace fossil archives must be addressed in future ichnofabric analyses to understand the likely spatio-temporal scale of their controls (local, regional or global). In the case of the crowded Skolithos ichnofabrics of the Alston Formation, regional environmental information is limited, but the ichnofauna provides a faithfully rendered and high-definition glimpse into life over a few weeks in an interdistributary bay from ca 330 million years ago.

\section{ACKNOWLEDGEMENTS}

HA was generously supported by a Judith McKenzie Field Work Award from the International Association of Sedimentologists. NSD was supported by Natural Environment Research Council grant number NE/T00696X. We would like to thank Alfred Uchman, Scott Melnyk, Murray Gingras and Associate Editor Gabriela Mángano for their constructive comments, which much improved this manuscript.

\section{DATA AVAILABILITY STATEMENT}

The data that support the findings of this study are available from the corresponding author upon reasonable request.

\section{REFERENCES}

Aitkenhead, N. and Riley, N.J. (1996) Kinderscoutian and Marsdenian successions in the Bradup and Hag Farm boreholes, near Ilkley, west Yorkshire. Proc. Yorkshire Geol. Soc., 51(2), 115-125.

Allen, J.R.L. (1981) Lower Cretaceous tides revealed by cross-bedding with mud drapes. Nature, 289(5798), 579581.

Aller, R.C. and Yingst, J.Y. (1978) Biogeochemistry of tubedwellings: a study of the sedentary polychaete Amphitrite ornata (Leidy). J. Mar. Res., 36, 201-254.

Archer, A.W. and Johnson, T.W. (1997) Modelling of cyclic tidal rhythmites (Carboniferous of Indiana and Kansas, Precambrian of Utah, USA) as a basis for reconstruction of intertidal positioning and palaeotidal regimes. Sedimentology, 44(6), 991-1010.

Archer, A.W., Kvale, E.P. and Johnson, H.R. (1991) Analysis of modern equatorial tidal periodicities as a test of information encoded in ancient tidal rhythmites. In: Clastic Tidal Sedimentology (Eds Smith, D.G., Reinson, G.E., Zaitlin, B.A. and Rahmani, R.A.), pp. 3-28. Canadian Society of Petroleum Geologists, Calgary, AB.

Archer, A.W., Kvale, E.P., Aitkenhead, N. and Riley, N.J,. (1997) Discussion of "Kinderscoutian and Marsdenian successions in the Bradup and Hag Farm boreholes, near Ilkley, West Yorkshire" Proceedings Vol. 51, part 2, pp.115-125, 1996. Proc. Yorkshire Geol. Soc., 51(4), 373374.

Bhattacharya, J.P., Howell, C.D., MacEachern, J.A. and Walsh, J.P. (2020) Bioturbation, sedimentation rates, and preservation of flood events in deltas. Palaeogeogr. Palaeoclimatol. Palaeoecol., 560, 110049.

Bhattacharya, J.P., Miall, A.D., Ferron, C., Gabriel, J., Randazzo, N., Kynaston, D., Jicha, B.R. and Singer, B.S. (2019) Time-stratigraphy in point sourced river deltas: Application to sediment budgets, shelf construction, and paleo-storm records. Earth Sci. Rev., 199, 102985.

Booth, M.G., Underhill, J.R., Gardiner, A. and McLean, D. (2020) Sedimentary and tectonic controls on Lower Carboniferous (Visean) mixed carbonate-siliciclastic deposition in NE England and the Southern North Sea: implications for reservoir architecture. Petrol. Geosci., 26 (2), 204-231.

Boyd, C. and McIlroy, D. (2017) Three-dimensional morphology of Beaconites capronus from Northeast England. Ichnos, 24(4), 250-258.

Boyd, C. and McIlroy, D. (2018) The morphology and mode of formation of Neoeione igen. nov. from the Carboniferous of northern England. PalZ, 92(1), 179-190.

Brettle, M.J., McIlroy, D., Elliott, T., Davies, S.J. and Waters, C.N. (2002) Identifying cryptic tidal influences within deltaic successions: an example from the Marsdenian (Namurian) interval of the Pennine Basin, UK. J. Geol. Soc., 159(4), 379-391.

Bromley, R.G. and Asgaard, U. (1991) Ichnofacies: a mixture of taphofacies and biofacies. Lethaia, 24(2), 153-163.

Buatois, L.A., Mangano, M.G. and Maples, C.G. (1997) The paradox of nonmarine ichnofaunas in tidal rhythmites; integrating sedimentologic and ichnologic data from the Late Cretaceous of eastern Kansas, USA. Palaios, 12(5), 467-481.

Buatois, L.A., Mangano, M.G., Maples, C.G. and Lanier, W.P. (1998) Ichnology of an upper Carboniferous fluvioestuarine paleovalley: The Tonganoxie sandstone, Buildex quarry, eastern Kansas, USA. J. Paleontol., 72(1), 152-180.

Carlton, R. and Summerling, N. (2017) The industrial heritage of cocklawburn. In: Peregrini Lindisfarne: An Anthology, pp. 1-10. Peregrini Lindisfarne, Lindisfarne. 
Chadwick, R.A., Holliday, D.W., Holloway, S. and Hulbert, A.G. (1995) The Structure and Evolution of the Northumberland-Solway Basin and Adjacent Areas. Subsurface Memoir of the British Geological Survey, HM Stationery Office, Keyworth. 109 pp.

Collinson, J.D. (1988). Controls on Namurian sedimentation in the Central Province basins of northern England. In Sedimentation in a synorogenic basin complex. The Upper Carboniferous of Northwest Europe, pp. 85-101.

Coughenour, C.L., Archer, A.W. and Lacovara, K.J. (2013) Calculating Earth-Moon system parameters from sub-yearly tidal deposit records: an example from the Carboniferous Tradewater Formation. Sed. Geol., 295, 67-76.

Cózar, P. and Somerville, I.D. (2012) The Carboniferous Archerbeck Borehole, near Canonbie (Dumfriesshire, southern Scotland): biostratigraphic revision of the late Asbian to early Pendleian succession using foraminiferans and regional correlations. Earth Environ. Sci. Trans. R. Soc. Edinburgh, 103(1), 105-122.

Cózar, P. and Somerville, I.D. (2020) Foraminiferal biostratigraphy of Brigantian-Arnsbergian limestones from eastern Scotland and Northumberland (northeast England). Earth Environ. Sci. Trans. R. Soc. Edinburgh, 111(3), 193-207.

Cózar, P. and Somerville, I.D. (2021) The Serpukhovian in Britain: use of foraminiferal assemblages for dating and correlating. J. Geol. Soc., 178(3), jgs2020-170

Curran, H.A. and Frey, R.W. (1977) Pleistocene trace fossils from North Carolina (USA), and their Holocene analogues. Trace Fossils, 2, 139-162.

Dalrymple, R.W., Makino, Y. and Zaitlin, B.A. (1991) Temporal and spatial patterns of rhythmite deposition on mud flats in the macrotidal Cobequid Bay-Salmon River estuary, Bay of Fundy, Canada. CSPG Memoir, 16, 137-160.

Dashtgard, S.E. (2011) Linking invertebrate burrow distributions (neoichnology) to physicochemical stresses on a sandy tidal flat: implications for the rock record. Sedimentology, 58(6), 1303-1325.

Dashtgard, S.E., Vaucher, R., Yang, B. and Dalrymple, R.W. (2021) Wave-Dominated to Tide-Dominated Coastal Systems: A Unifying Model for Tidal Shorefaces and Refinement of the Coastal-Environments Classification Scheme. Geosci. Can., 48(1), 5-22.

Davies, N.S., Herringshaw, L.G. and Raine, R.J. (2009) Controls on trace fossil diversity in an Early Cambrian epeiric sea: new perspectives from northwest Scotland. Lethaia, 42(1), 17-30.

Davies, N.S. and Shillito, A.P. (2018) Incomplete but intricately detailed: The inevitable preservation of true substrates in a time-deficient stratigraphic record. Geology, 46(8), 679-682.

Davies, N.S., Shillito, A.P. and McMahon, W.J. (2019) Where does the time go? Assessing the chronostratigraphic fidelity of sedimentary geological outcrops in the PliocenePleistocene Red Crag Formation, eastern England. J. Geol. Soc., 176(6), 1154-1168.

Davies, N.S. and Shillito, A.P. (2021) True substrates: the exceptional resolution and unexceptional preservation of deep time snapshots on bedding surfaces. Sedimentology. http://dx.doi.org/10.1111/sed.12900

Davis, R.A. (2012) Tidal signatures and their preservation potential in stratigraphic sequences. In: Principles of Tidal Sedimentology (Eds Davis, R.A. and Dalrymple, R.W.), pp. 35-55. Springer, Dordrecht.

De Boer, P.L., Oost, A.P. and Visser, M.J. (1989) The diurnal inequality of the tide as a parameter for recognizing tidal influences. J. Sediment. Res., 59(6), 912-921.
Dean, M.T., Browne, M.A.E., Waters, C.N. and Powell, J.H. (2011) A lithostratigraphical framework for the Carboniferous successions of northern Great Britain (onshore). British Geological Survey Research Report RR/ 10/07.

Diggle, P.J. (2013) Statistical Analysis of Spatial and SpatioTemporal Point Patterns. CRC Press, Delhi.

Ekdale, A.A. (1985) Paleoecology of the marine endobenthos. Palaeogeogr. Palaeoclimatol. Palaeoecol., 50(1), 63-81.

Ekdale, A.A., Bromley, R.G. and Pemberton, S.G. (1984) Ichnology: The use of trace fossils in sedimentology and stratigraphy. SEPM Short Course, 15, 317.

Emig, C.C. (1982) The biology of Phoronida. Adv. Mar. Biol., 19, 1-89.

Emig, C.C. (2010) Fossil Phoronida and their inferred ichnotaxa. Carnets de géologie. Note brève 2010/03.

Emig, C.C. and de Mittelwihr, C. (1999) What is a phoronid? Available at http://paleopolis.rediris.es/Phoronida/

Fielding, C.R. (2021) Late Palaeozoic cyclothems-A review of their stratigraphy and sedimentology. Earth Sci. Rev., 217, 103612.

Frank, M.C. and Tyson, R.V. (1995) Parasequence-scale organic facies variations through an early Carboniferous Yoredale cyclothem, Middle Limestone Group, Scremerston, Northumberland. J. Geol. Soc., 152(1), 41-50.

Fraser, A.J. and Gawthorpe, R.L. (2003) An atlas of Carboniferous basin evolution in northern England. Geol. Soc., London. Memoir, 28, 79.

Ganti, V., Hajek, E.A., Leary, K., Straub, K.M. and Paola, C. (2020) Morphodynamic hierarchy and the fabric of the sedimentary record. Geophys. Res. Lett., 47(14), e2020GL087921.

Gingras, M.K., Pemberton, S.G., Dashtgard, S. and Dafoe, L. (2008) How fast do marine invertebrates burrow? Palaeogeogr. Palaeoclimatol. Palaeoecol., 270(3-4), 280286.

Gingras, M.K. and Zonneveld, J.P. (2015) Tubular tidalites: a biogenic sedimentary structure indicative of tidally influenced sedimentation. J. Sediment. Res., 85(7), 845854.

Holbrook, J.M. and Miall, A.D. (2020) Time in the rock: a field guide to interpreting past events and processes from siliciclastic stratigraphy. Earth Sci. Rev., 203, 103121. http://dx.doi.org/10.1016/j.earscirev.2020.103121

Illian, J., Penttinen, A., Stoyan, H. and Stoyan, D. (2008) Statistical Analysis and Modelling of Spatial Point Patterns, Volume 70. John Wiley \& Sons, New York.

Ingrams, S., McLean, D., Booth, M. and Bodman, D.J. (2020) Biostratigraphy and paleoecology of Asbian-Brigantian (Mississippian) miospores from Berwick-upon-Tweed, Northumberland, UK: Preliminary results. Rev. Palaeobot. Palynol., 276, 104206.

Jones, N.S. (2007) The Scremerston Formation: Results of a Sedimentological Study of Onshore Outcrop Sections and Offshore Well 42/13-2. Marine, Coastal and Hydrocarbons Programme Commissioned Report CR/07/101. British Geological Survey, Keyworth, Nottingham, 70 pp.

Keighley, D.G. and Pickerill, R.K. (1995) Commentary: the ichnotaxa Palaeophycus and Planolites: historical perspectives and recommendations. Ichnos, 3, 301-309.

Keighley, D.G. and Pickerill, R.K. (2003) Ichnocoenoses from the Carboniferous of eastern Canada and their implications for the recognition of ichnofacies in nonmarine strata. Atlantic Geol., 39, 1-22. 
Knaust, D. (2010) Meiobenthic trace fossils comprising a miniature ichnofabric from Late Permian carbonates of the Oman Mountains. Palaeogeogr. Palaeoclimatol. Palaeoecol., 286(1-2), 81-87.

Knaust, D. (2017) Atlas of Trace Fossils in Well Core: Appearance, Taxonomyand Interpretation. Springer, New York.

Knaust, D. (2018) The ichnogenus Teichichnus Seilacher, 1955. Earth Sci. Rev., 177, 386-403.

Knaust, D., Thomas, R.D. and Curran, H.A. (2018) Skolithos linearis Haldeman, 1840 at its early Cambrian type locality, Chickies Rock, Pennsylvania: analysis and designation of a neotype. Earth Sci. Rev., 185, 15-31.

Kvale, E.P. (2006) The origin of neap-spring tidal cycles. Mar. Geol., 235(1-4), 5-18.

Kvale, E.P. (2012) Tidal constituents of modern and ancient tidal Rhythmites: criteria for recognition and analyses. In: Principles of Tidal Sedimentology (Eds Davis, R.A. and Dalrymple, R.W.), pp. 1-17. Springer, Dordrecht.

Larson, A.A. and Stachowicz, J.J. (2009) Chemical defense of a soft-sediment dwelling phoronid against local epibenthic predators. Mar. Ecol. Prog. Ser., 374, 101-111.

Leeder, M.R., Fairhead, D., Lee, A., Stuart, G. and Clemmey, H. (1989) Sedimentary and tectonic evolution of the Northumberland Basin. In: The Role of Tectonics in Devonian and Carboniferous Sedimentation in the British Isles (Eds Arthurton, R.J., Gutteridge, P. and Nolan, S.C.), Yorkshire Geological Society Occasional Publication, 6, 207-223.

MacEachern, J.A. and Bann, K.L. (2020) The Phycosiphon Ichnofacies and the Rosselia Ichnofacies: Two new ichnofacies for marine deltaic environments. J. Sediment. Res., 90(8), 855-886.

Marenco, K.N. and Hagadorn, J.W. (2019) Big bedding planes: Outcrop size and spatial heterogeneity influence trace fossil analyses. Palaeogeogr. Palaeoclimatol. Palaeoecol., 513, 14-24.

Mazumder, R. and Arima, M. (2005) Tidal rhythmites and their implications. Earth Sci. Rev., 69(1-2), 79-95.

McIlroy, D. (2004) Some ichnological concepts, methodologies, applications and frontiers. Geol. Soc., London, Spec. Public., 228(1), 3-27.

McIlroy, D. and Garton, M. (2010) Realistic interpretation of ichnofabrics and palaeoecology of the pipe-rock biotope. Lethaia, 43(3), 420-426.

McLean, D., Booth, M., Bodman, D.J. and McLean, F.D. (2020) Carboniferous records of the Zoophycos group of trace fossils from England, Wales, the Isle of Man and the North Sea. Proc. Yorkshire Geol. Soc., 63(2), 135-145.

Miall, A.D. (2015) Updating uniformitarianism: stratigraphy as just a set of 'frozen accidents'. Geol. Soc., London, Spec. Public., 404(1), 11-36.

Miller, M.F. and Smail, S.E. (1997) A semiquantitative field method for evaluating bioturbation on bedding planes. Palaios, 12(4), 391-396.

Mitchell, E.G. and Butterfield, N.J. (2018) Spatial analyses of Ediacaran communities at Mistaken Point. Paleobiology, 44(1), 40-57.

Mitchell, E.G. and Harris, S. (2020) Mortality, Population and Community Dynamics of the Glass Sponge Dominated Community "The Forest of the Weird" From the Ridge Seamount, Johnston Atoll, Pacific Ocean. Front. Marine Sci., 7, 872.

Myrow, P.M., Lamb, M.P. and Ewing, R.C. (2018) Rapid sea level rise in the aftermath of a Neoproterozoic snowball Earth. Science, 360(6389), 649-651.
Nara, M. (1995) Rosselia socialis: a dwelling structure of a probable terebellid polychaete. Lethaia, 28(2), 171-178.

Nio, S.D. and Yang, C.S. (1991) Diagnostic attributes of clastic tidal deposits: a review. In: Clastic Tidal Sedimentology (Eds Smith, D.G., Reinson, G.E., Zaitlin, B.A. and Rahmani, R.A.), pp. 3-28. Canadian Society of Petroleum Geologists, Calgary, AB.

Northumberland County Council (2012) Cell 1 Regional Coastal Monitoring Programme: Walk-over Visual Inspections of Assets; Northumberland County Council Final Report November 2012. Available from: https:// www.northeastcoastalobservatory.org.uk/data/reports/

Northumberland County Council (2020) Cell 1 Regional Coastal Monitoring Programme Walkover Inspection Surveys 2020. Available from: https://www. northeastcoastalobservatory.org.uk/data/reports/

O’Mara, P.T., Merryweather, M., Stockwell, M. and Bowler, M.M. (1999) The Trent Gas Field: correlation and reservoir quality within a complex Carboniferous stratigraphy. Geol. Soc., London, Petrol. Geol. Conf. Ser., 5(1), 809-821.

Paola, C., Ganti, V., Mohrig, D., Runkel, A.C. and Straub, K.M. (2018) Time not our time: Physical controls on the preservation and measurement of geologic time. Annu. Rev. Earth Planet. Sci., 46, 409-438.

Pemberton, S.G. and Frey, R.W. (1984) Quantitative methods in ichnology: spatial distribution among populations. Lethaia, 17(1), 33-49.

Pickerill, R.K. (1992) Carboniferous nonmarine invertebrate ichnocoenoses from southern New Brunswick, eastern Canada. Ichnos, 2(1), 21-35.

Pollard, J.E., Goldring, R. and Buck, S.G. (1993) Ichnofabrics containing Ophiomorpha: significance in shallow-water facies interpretation. J. Geol. Soc., 150(1), 149-164.

Read, W.A. (1992) Evidence of tidal influences in Arnsbergian rhythmites in the Kincardine Basin. Scott. J. Geol., 28(2), 135-142.

Reynaud, J.Y. and Dalrymple, R.W. (2012) Shallow-marine tidal deposits. In: Principles of Tidal Sedimentology (Eds Davis, R.A. and Dalrymple, R.W.), pp. 335-369. Springer, Dordrecht.

Reynolds, A.D. (1992) Storm, wave and tide-dominated sedimentation in the Dinantian Middle Limestone Group, Northumbrian Basin. Proc. Yorkshire Geol. Soc., 49(2), 135-148.

Richards, B.C. (2013) Current status of the international Carboniferous time scale. Bull. New Mexico Mus. Nat. His., 60, 348-353.

Rodríguez-Tovar, F.J., Mayoral, E., Santos, A., Dorador, J. and Wetzel, A. (2019) Crowded tubular tidalites in Miocene shelf sandstones of southern Iberia. Palaeogeogr. Palaeoclimatol. Palaeoecol., 521, 1-9.

Ronan, T.E. (1978) Food-resources and the influence of spatial pattern on feeding in the phoronid Phoronopsis viridis. Biol. Bull., 154(3), 472-484.

Santagata, S. (2015) Phoronida. In: Evolutionary Developmental Biology of Invertebrates 2: Lophotrochozoa (Spiralia) (Ed. Wanninger, A.), pp. 231-245. Springer, Vienna.

Schäfer, W. (1972) Ecology and Paleoecology Of Marine Environments. Oliver \& Boyd, Edinburgh, $568 \mathrm{pp}$.

Shillito, A.P. and Davies, N.S. (2020) The Tumblagooda Sandstone revisited: exceptionally abundant trace fossils and geological outcrop provide a window onto Palaeozoic littoral habitats before invertebrate terrestrialization. Geol. Mag., 157(12), 1939-1970. 
Sundberg, F.A. (1983) Skolithos linearis Haldeman from the Carrara Formation (Cambrian) of California. J. Paleontol., 145-149.

Tarhan, L.G., Droser, M.L., Planavsky, N.J. and Johnston, D.T. (2015) Protracted development of bioturbation through the early Palaeozoic Era. Nat. Geosci., 8(11), 865-869.

Taylor, A.M. and Goldring, R. (1993) Description and analysis of bioturbation and ichnofabric. J. Geol. Soc., 150 (1), 141-148.

Thiel, M. and Kruse, I. (2001) Status of the Nemertea as predators in marine ecosystems. Hydrobiologia, 456(1), 21-32.

Tipper, J.C. (2015) The importance of doing nothing: stasis in sedimentation systems and its stratigraphic effects. Geol. Soc., London, Spec. Public., 404(1), 105-122.

Torsvik, T.H. and Cocks, L.R.M. (2016) Earth History and Palaeogeography. Cambridge University Press, Cambridge.

Tucker, M.E., Gallagher, J. and Leng, M.J. (2009) Are beds in shelf carbonates millennial-scale cycles? An example from the mid-Carboniferous of northern England. Sed. Geol., 214(1-4), 19-34.

Turner, B.R. and Scrutton, C. (1995) The Carboniferous rocks around Berwick-upon-tweed. In: Northumbrian rocks and landscape: a field guide (pp. 42-52). Yorkshire Geological Society, Yorkshire.

Turner, N. and Spinner, E. (1992) Palynological evidence for the early Namurian age of the "Millstone Grit" and Upper
Limestone Group around Longhoughton Steel, Northumberland. Proc. Yorkshire Geol. Soc., 49(1), 11-22.

Wells, M.R., Allison, P.A., Hampson, G.J., Piggott, M.D. and Pain, C.C. (2005) Modelling ancient tides: the Upper Carboniferous epi-continental seaway of Northwest Europe. Sedimentology, 52(4), 715-735.

Wells, M.R., Allison, P.A., Piggott, M.D., Hampson, G.J., Pain, C.C. and Gorman, G.J. (2010) Tidal modeling of an ancient tide-dominated seaway, part 2: the Aptian Lower Greensand Seaway of Northwest Europe. J. Sediment. Res., 80(5), 411-439.

Wiegand, T. and Moloney, K.A. (2013) Handbook of Spatial Point-Pattern Analysis in Ecology. CRC Press, New York.

Williams, G.E. (1989) Late Precambrian tidal rhythmites in South Australia and the history of the Earth's rotation. J. Geol. Soc., 146(1), 97-111.

Waters C.N., Millward D., Thomas C.W. (2014) The millstone grit group (Pennsylvanian) of the Northumberland-Solway basin and alston block of northern England. Proceedings of the Yorkshire Geological Society, 60(1), 29. http://dx.doi.org/10.1144/pygs2014-341

Manuscript received 27 April 2021; revision 20 August 2021; revision accepted 20 September 2021 